WSRC-TR--92-346

DE93 002808

Keywords: glass, DWPF, durability standard, redox standard, chemical standard

\title{
CHARACTERIZATION OF THE DEFENSE WASTE PROCESSING FACILITY (DWPF) ENVIRONMENTAL ASSESSMENT (EA) GLASS STANDARD REFERENCE MATERIAL (U)
}

\section{M. JANTZEN, N.E. BIBLER, AND D.C. BEAM}

Approved by

E.W. Holtzscheiter, Research Manager

Defense Waste Processing Technology

Publication Date: September 30, 1992

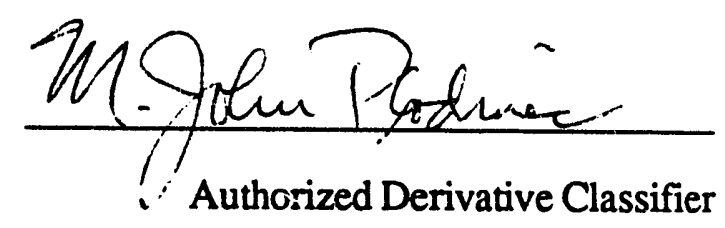

\section{Westinghouse Savannah River Co. Savannah River Site Aiken, SC 29808}

PREPARED FOR THE U.S. DEPARTMENT OF ENERGY UNDER CONTRACT DE-AC09.89SR18035

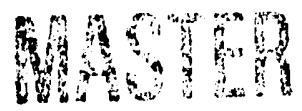


This page intentionally left blank.

-2 . 


\section{ABSTRACT}

Liquid high-level nuclear waste at the Savannah River Site (SRS) will be immobilized by vitrification in borosilicate glass. The glass will be produced and poured into stainless steel canisters in the Defense Waste Processing Facility (DWPF). Other waste form producers, such as West Valley Nuclear Services (WVNS) and the Hanford Waste Vitrification Project (HWVP), will also immobilize high-level radioactive waste in borosilicate glass. The canistered waste will be stored temporarily at each facility for eventual permanent disposal in a geologic repository. The Department of Energy has defined a set of requirements for the canistered waste forms, the Waste Acceptance Preliminary Specifications (WAPS). The current Waste Acceptance Preliminary Specification (WAPS) 1.3, the product consistency specification, requires the waste form producers to demonstrate control of the consistency of the final waste form using a crushed glass durability test, the Product Consistency Test (PCT). In order to be acceptable, a waste glass must be more durable during PCT analysis than the waste glass identified in the DWPF Environmental Assessinent (EA). In order to supply all the waste form producers with the same standard benchmark glass, 1000 pounds of the EA glass was fabricated. The chemical analyses and characterization of the benchmark EA glass are reported. This material is now available to act as a durability, analytic, and/or redox Standard Reference Material (SRM) for all waste form producers. 
This page intentionally left blank.

-4 - 


\section{TABLE OF CONTENTS}

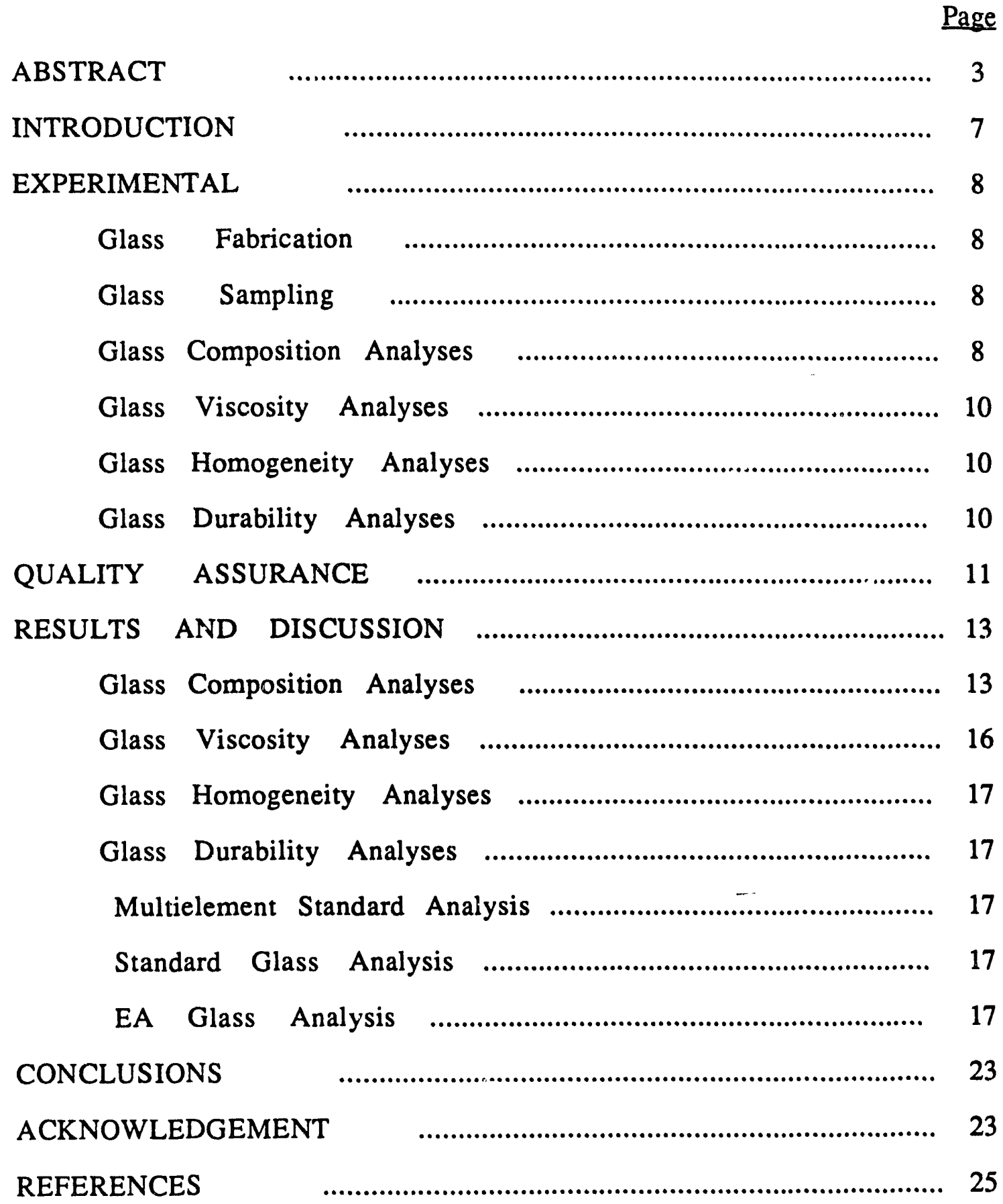




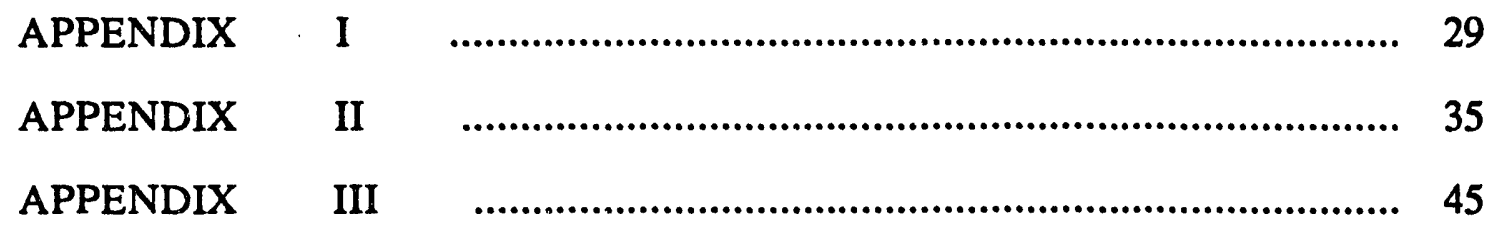




\section{CHARACTERIZATION OF THE DEFENSE WASTE PROCESSING FACILITY (DWPF) ENVIRONMENTAL ASSESSMENT (EA) GLASS STANDARD REFERENCE MATERIAL (U)}

\section{INTRODUCTION}

Waste form producers at the Savannah River Site (SRS), West Valley Nuclear Services (WVNS), and Hanford Waste Vitrification Project (HWVP) will immobilize high-level radioactive waste in borosilicate glass. The glass will be poured into stainless steel canisters for eventual disposal in a geologic repository. The Department of Energy has defined a set of requirements for the canistered waste forms, the Waste Acceptance Preliminary Specifications (WAPS). ${ }^{1}$

The current Waste Acceptance Preliminary Specification (WAPS) 1.3, the product consistency specification, requires the waste form producers to demonstrate control of the consistency of the final waste form using the Product Consistency Test (PCT). ${ }^{2-5}$ The PCT is a crushed glass durability test which is (1) sensitive to glass composition and homogeneity, and (2) may have the potential to be related to repository site-specific release tests. It is a glass dominated production test which can be used to test glasses during production, even in the shielded cell environments necessitated by highly radioactive glasses. $2-7$ A standard glass is always measured simuitaneously to an unknown during PCT analysis.

The WAPS 1.3 specification defines the acceptance criterion for a production glass: a waste glass being produced must be more durable during PCT analysis than the waste glass identified in the DWPF Environmental Assessment (EA). 8 During simultaneous PCT analysis of the production glass and the EA glass, the latter can be used as the standard glass required by the PCT protocol.

The WAPS 1.1.2 requires that the waste form producers report the measured chemical composition of the glass waste form in the Production Records. The Defen'se Waste Processing Facility (DWPF) process/product models relate important processing and product quality requirements to glass composition. ${ }^{9}$ Routine chemical analyses of vitrified feed samples is required. In addition, control of the oxidation/reduction (redox) equilibrium in the glass melter is criticil for processing of the nuclear waste. ${ }^{10-15}$ As part of the DWPF process control strategy, the glass redox expected in the melter will be determined by measuring the ratio of $\mathrm{Fe}^{2+} / \Sigma \mathrm{Fe}$ in vitrified slurry. 16 -

17 Routine redox analyses of vitrified feed samples is required. A glass standard with a known redox and composition, such as the EA glass, will need to be run simultaneously with the production glass or vitrified feed in order to minimize error and long term instrumental bias. 18,19

In order to supply the DWPF and all the waste form producers with the same standard benchmark glass, the Savannah River Technology Center (SRTC) had 1000 pounds of the EA glass fabricated by Corning Glass Works (AX-AA28362A). The chemical analyses and characterization of the berichmark EA glass, to be used as a durability, analytic, and/or redox Standard Reference Material, are reported in this study. 


\section{EXPERIMENTAL}

\section{Glass Fabrication}

The composition of the glass as given in the DWPF Environmental Assessment ${ }^{8}$ is shown in Table 1. The target composition of the glass to be fabricated is also given in Table 1. The target EA glass composition was derived from the composition given in the $\mathrm{EA}^{8}$ by the following calculational procedure:

- recalculating the $\mathrm{MnO}_{2}$ as $\mathrm{MnO}$ due to the reduced nature of this glass

- recalculating the $\mathrm{Fe}_{3} \mathrm{O}_{4}$ as $\mathrm{Fe}_{2} \mathrm{O}_{3}$ and $\mathrm{FeO}$

- calculating "other solids" as primarily zeolite 20

- deleting the $\mathrm{U}_{3} \mathrm{O}_{8}$ component due to the difficulty of handling and shipping uranium bearing glass as a Standard Reference Material

- normalizing to $100 \mathrm{wt} \%$

Corning Glass Works fabricated the glass in a gas fired atmospheric furnace with an oxygen:natural gas mixture of $2: 1$ to control the redox of the atmosphere. The iron was added as ferric iron oxide $\left(\mathrm{Fe}_{2} \mathrm{O}_{3}\right)$ and ferrous iron oxalate dihydrate $\left(\mathrm{FeC}_{2} \mathrm{O}_{4} \cdot 2 \mathrm{H}_{2} \mathrm{O}\right)$. Five pounds of carbocite carbon were added per master batch of 1203 pounds of glass to reduce the glass during melting and to be able to control the redox with the gas mixture more efficiently. The batch was melted at $1250^{\circ} \mathrm{C}$ and $\mathrm{N}_{2}$ was bubbled through the batch to assist in homogenizing the glass. The glass was kept at $110^{\circ} \mathrm{C}$ while it was being drained and water quenched to ensure that devitrification did not occur. The glass melt adsorbed water during quenching and was air dried in a Peterson Kelly (PK) blender to prevent particle agglomeration.

\section{Glass Sampling}

The glass was received in three large drums. A stainless steel tube of $\sim 1 / 2$ inch diameter was used under vacuum to sample glass from the bottom, middle, and top of each drum. A similar technique had been used at Corning Glass Works for glass sampling after fabrication.

\section{Glass Composition Analyses}

Corning Glass Works analyzed five samples of the EA glass after fabrication. Each sample was dissolved in triplicate. The fifteen dissolutions were analyzed in duplicate for $\mathrm{Al}, \mathrm{B}, \mathrm{Ca}, \mathrm{Fe}, \mathrm{K}$, $\mathrm{La}, \mathrm{Li}, \mathrm{Mg}, \mathrm{Mn}, \mathrm{Na}, \mathrm{Ni}, \mathrm{Si}, \mathrm{Ti}, \mathrm{Zr}$, and $\mathrm{Fe}^{2+} / \mathrm{Fe}^{3+}$ on different days to include any short time instrumental bias in the measurement of the standard deviation. The average and standard deviation of the 30 replicate EA glass analyses measured by Corning Glass Works is given in Table 1. Details of the analyses are given in Appendix I. 
Table 1. Comparison of EA Glass Composition, Target Glass Composition, and Corning Glass Works Analyzed Glass Composition

\section{$\begin{array}{lll}\text { Composition } & \begin{array}{l}\text { Target Glass } \\ \text { Composition }\end{array} & \begin{array}{l}\text { Works Analyzed } \\ \text { Glass Composition* Glass Composition }\end{array}\end{array}$}

\begin{tabular}{|c|c|c|c|c|}
\hline $\mathrm{Al}_{2} \mathrm{O}_{3}$ & 3.2 & $3.67 \pm 0.18^{t}$ & $3.70 \pm 0.023$ & $3.60 \pm 0.12$ \\
\hline $\mathrm{B}_{2} \mathrm{O}_{3}$ & 10.9 & $11.12 \pm 0.556^{\mathrm{t}}$ & $11.3 \pm 0.097$ & $11.16 \pm 0.17$ \\
\hline $\mathrm{CaO}$ & 1.0 & $1.13 \pm 0.06^{t}$ & $1.12 \pm 0.007$ & $1.23 \pm 0.09$ \\
\hline $\mathrm{Fe}_{2} \mathrm{O}_{3}$ & 5.9 & $8.08 \pm(\text { see redox })^{\ddagger}$ & $7.38 \pm 0.074$ & $7.58 \pm 0.41$ \\
\hline $\mathrm{FeO}$ & & $0.89 \pm($ see redox $) \ddagger$ & $1.45 \pm 0.041$ & $1.59 \pm 0.06$ \\
\hline $\mathrm{Fe}_{3} \mathrm{O}_{4}$ & 2.8 & & & \\
\hline $\mathrm{K}_{2} \mathrm{O}$ & & $0.04 \pm 0.004$ & $0.04 \pm 0.000$ & $0.04 \pm 0.01$ \\
\hline $\mathrm{La}_{2} \mathrm{O}_{3}$ & 0.4 & $0.41 \pm 0.04$ & $0.42 \pm 0.005$ & $0.28 \pm 0.02$ \\
\hline $\mathrm{Li}_{2} \mathrm{O}$ & 4.2 & $4.28 \pm 0.21^{t}$ & $4.26 \pm 0.015$ & $4.21 \pm 0.15$ \\
\hline $\mathrm{MgO}$ & 1.6 & $1.66 \pm 0.08^{t}$ & $1.72 \pm 0.011$ & $1.79 \pm 0.07$ \\
\hline $\mathrm{MnO}$ & & $1.34 \pm 0.07^{t}$ & $1.34 \pm 0.01$ & $1.36 \pm 0.05$ \\
\hline $\mathrm{MnO}_{2}$ & 1.6 & & & \\
\hline $\mathrm{Na}_{2} \mathrm{O}$ & 16.3 & $16.71 \pm 0.84^{\mathrm{t}}$ & $16.8 \pm 0.061$ & $16.88 \pm 0.32$ \\
\hline $\mathrm{NiO}$ & 0.6 & $0.61 \pm 0.06$ & $0.57 \pm 0.005$ & $0.53 \pm 0.03$ \\
\hline $\mathrm{SiO}_{2}$ & 46.3 & $48.95 \pm 4.90$ & $48.73 \pm 0.302$ & $48.76 \pm 0.82$ \\
\hline $\mathrm{TiO}_{2}$ & 0.7 & $0.71 \pm 0.07$ & $0.70 \pm 0.006$ & $0.65 \pm 0.03$ \\
\hline $\mathrm{U}_{3} \mathrm{O}_{8}$ & 1.2 & & & \\
\hline $\mathrm{ZnO}$ & & & & $0.26 \pm 0.04$ \\
\hline $\mathrm{ZrO}_{2}$ & 0.4 & $0.41 \pm 0.04$ & $0.46 \pm 0.012$ & $0.48 \pm 0.08$ \\
\hline Other Solidst & 2.9 & 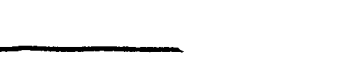 & - & - \\
\hline SUM & 100.00 & 100.01 & 99.99 & 100.41 \\
\hline $\mathrm{Fe}^{2+} / \mathrm{Fe}^{3+}$ & 0.123 & 0.1 to 0.3 & $0.22 \pm 0.01$ & $0.23 \pm 0.01$ \\
\hline
\end{tabular}

* average and standard deviation of 30 replicate analyses are given in Appendix I

tt where other solids include zeolite, undissolved salts, and radionuclides $(<0.1 \% \text { of the waste })^{8}$

$t$ corresponds to 5 relative wt\%, all others are 10 relative wt\%

$+\quad$ values based on $\mathrm{Fe}^{2+} / \mathrm{Fe}^{3+}=0.123$; actual values vary on exact ratio of $\mathrm{Fe}^{2+} / \mathrm{Fe}^{3+}$ achieved between the specified range of 0.1 to 0.3 
The Analytic Development Section of the Savannah River Technology Center analyzed ten samples of the EA glass and two Purex glass standards to determine the glass composition. Twelve samples of the EA glass were measured for redox. The EA glass samples were analyzed by the following techniques:

- Dissolution by $\mathrm{Na}_{2} \mathrm{O}_{2}$ with an $\mathrm{HCl}$ uptake

- ICP for Al, Si, B

- Dissolution by $\mathrm{HCl} / \mathrm{HF}$ microwave

- ICP for $\mathrm{Na}, \mathrm{Zr}, \mathrm{Ca}, \mathrm{Fe}, \mathrm{Mg}, \mathrm{Mn}, \mathrm{Li}, \mathrm{Cr}, \mathrm{Sr}, \mathrm{Ti}, \mathrm{P}, \mathrm{Ba}, \mathrm{Pb}, \mathrm{Mo}, \mathrm{Zn}, \mathrm{Cu}, \mathrm{Ni}, \mathrm{La}$

- AA for Na, K, Cs

- Dissolution by $\mathrm{Na}_{2} \mathrm{O}_{2}$ with a $\mathrm{H}_{2} \mathrm{O}$ uptake

- IC for $\mathrm{SO}_{4}, \mathrm{NO}_{3}$, and $\mathrm{PO}_{4}$

- ISE for $\mathrm{Cl}$ and $\mathrm{F}$

- Dissolution by $\mathrm{H}_{2} \mathrm{SO}_{4} / \mathrm{HF}$ in the presence of $\mathrm{NH}_{4} \mathrm{VO}_{3}{ }^{21}$

- Colorimetric for $\mathrm{Fe}^{2+}$ and total $\mathrm{Fe}(\Sigma \mathrm{Fe})$

where ICP is Inductively Coupled Plasma Spectroscopy, AA is Atomic Absorption analysis, IC is Ion Chromatography analysis, and ISE is Ion Selective Electrode analysis.

\section{Glass Viscosity Analyses}

A five-point high temperature viscosity analysis was performed on a Brookfield Viscometer according to ASTM-C-965A by Sharp-Schurtz Analytical Division of Owens/Corning Fiberglas Corporation.

\section{Glass Homogeneity Analyses}

X-ray Diffraction (XRD) and Scanning Electron Microscopy (SEM) analyses coupled with Energy Dispersive Analysis by X-ray (EDAX) were performed on the EA glass in order to determine the crystallinity and/or homogeneity of the glass.

\section{Glass Durability Analyses}

The durability of the EA glass was examined using Version 3.0 of the PCT.$^{3}$ In the PCT analysis, crushed glass of 100-200 mesh is immersed in ASTM Type I water for 7 days at $90^{\circ} \mathrm{C}$. The surface area of the glass exposed in 100-200 mesh glass can be calculated using an assumed waste glass density ( $-2.76 \mathrm{~g} / \mathrm{cc}$ for average SRS glasses) and by assuming a Gaussian distribution of particle sizes. Since the volume of leachant solution $(V)$ is maintained at $10 \mathrm{~mL}$ per gram of glass, the ratio of the glass surface area (SA) to the volume (V) of leachant is $19.55 \mathrm{~cm}^{-1}$. PCT leachates were filtered to remove colloids and/or particulates. The leachates were analyzed for $\mathrm{pH}$ and the elemental concentration of the glass species of interest. 
Three researchers completed PCT analysis of the EA glass. The first researcher completed triplicate analyses of two EA glass samples in $60 \mathrm{~mL} 75$ psi Teflon ${ }^{\circledR}$ vessels. The second researcher completed six replicate PCT analyses of one EA glass sample in the same type of

Teflon ${ }^{\circledR}$ vessel. The third researcher completed quadruplicate PCT analyses of one EA glass sample in the same type of Teflon ${ }^{\circledR}$ vessels. The third researcher also ran two sets of quadruplicate PCT analyses of the EA glass in 22mL 304L stainless steel Parr bombs with a well polished surface interior finish. One set of tests in the steel vessels used $19 \mathrm{~mL}$ of ASTM-Type I water leaving zero head space for air in the vessel. The second set of PCT analyses was performed on the EA glass in the $22 \mathrm{~mL}$ Parr bombs with only $15 \mathrm{~mL}$ of ASTM-Type I water leaving $4 \mathrm{~mL}$ head space for air in the vessel.

A standard glass, ARM-1 was used by all the researchers to ascertain if long term bias in the experimental analysis had occurred compared to previous glasses tested at SRS. Replicate PC $\Gamma$ tests on the EA glass and on the glass standards were run simultaneously.

A multielement solution standard was used by all the researchers to ensure that instrumental drift in the Inductively Coupled Plasma (ICP) Spectroscopy and/or Atomic Absorption (AA) analyses did not bias the short term leachate analyses. Duplicate durability tests containing ASTM Type I water but no glass samples were run simultaneously with each set of samples as "blanks." All conditions, including the type of vessel and the head space in the vessel were kept the same for the blank tests and the EA glass tests. The use of blanks ensures that the test vessel preparation was adequate and that the sample leachates can be corrected for elemental variation occurring independently of the glass-solution interactions.

\section{QUALITY ASSURANCE}

All melting and glass analyses performed at Corning Glass Works were carried out in accordance with RW-0214 and NQA-1. All glass physical property measurements performed at Owens Corning Fiberglas were carried out in accordance with RW-0214 and NQA-1. All glass analyses performed at the Savannah River Technology Center were carried out in accordance with RW0214 and NQA-1. The data for the chemical analyses performed at Corning Glass Works and at SRS are recorded in WSRC-NB-91-237 and WSRC-NB-92-129. The XRD, SEM, EDAX analyses performed at SRS and the viscosity analyses performed at Owens Corning Fiberglas are recorded in the same notebook. The glass durability data of the first and second researchers is recorded in WSRC-NB-91-199 and WSRC-NB-91-200, respectively. The data of the third researcher is recorded in DPSTN-4793. 
This page intentionally left blank. 


\section{RESULTS AND DISCUSSION}

\section{Glass Composition Analyses}

Ten replicates of the EA glass were analyzed chemically at the Savannah River Technology Center. Detailed results for each analysis are given in Appendix II. Duplicate analyses of a glass standard from the Waste Compliance Plan, 22 the WCP Purex glass, were run simultaneously. The analysis included a redox measurement so that the total Fe could be speciated as $\mathrm{Fe}_{2} \mathrm{O}_{3}$ and $\mathrm{FeO}$. The analytic values for $\mathrm{Al}_{2} \mathrm{O}_{3}, \mathrm{SiO}_{2}$, and $\mathrm{Na}_{2} \mathrm{O}$ were biased low compared to the standard Purex glass analysis. An average bias correction for these oxides 'vere calculated from the duplicate Purex glass analyses and applied to the analyses of the ten replicate EA glass samples (Appendix II). The average oxide $w t \%$ bias for $\mathrm{Al}_{2} \mathrm{O}_{3}$ ranged from 4 to 6.7 , while the average bias for $\mathrm{SiO}_{2}$ and $\mathrm{Na}_{2} \mathrm{O}$ ranged from 1.5 to 2.9 and 4.3 to 4.4 , respectively. The average oxide wt $\%$ bias corrections used were 5,2 , and 4 for $\mathrm{Al}_{2} \mathrm{O}_{3}, \mathrm{SiO}_{2}$, and $\mathrm{Na}_{2} \mathrm{O}$, respectively.

The bias corrected analyses for the ten replicate EA glass samples is given in Table 2 with the Fe speciated as $\mathrm{Fe}_{2} \mathrm{O}_{3}$ and $\mathrm{FeO}$ based on the measured redox which is also given in Table 2 . The composition of the 1000 pounds of EA glass, including the redox, appears to be homogeneous: there are no chemical differences between the glass samples from the three drums, nor from the glass sampled from the top, middle, or bottom of each drum.

The average composition and the standard deviations of the EA glass composition measurement at SRTC are also given in Table 2 . These values are compared to the target glass analyses and to the Corning Glass Works composition in Table 1 . One sample from drum two (2-MISC) appears to be significantly different than the other analyses in terms of its $\mathrm{Fe}_{2} \mathrm{O}_{3}, \mathrm{~B}_{2} \mathrm{O}_{3}$, and $\mathrm{SiO}_{2}$ content.

Although this analysis is considered deviate, the average and standard deviations given in Table 2 are based on all ten replicate analyses.

Within the standard deviations of the replicate analyses of both laboratories the analyses verify that the 1000 pounds of EA glass is within the target glass composition specified. The redox analyses measured by SRTC agree to within 0.01 of the values measured by Corning Glass Works. The SRTC analyses agree closely with the Corning Glass Works analyses except for minor component and anion analysis, e.g. $\mathrm{La}_{2} \mathrm{O}_{3}, \mathrm{ZnO}, \mathrm{Cl}$, and $\mathrm{F}$. The SRTC values for $\mathrm{La}_{2} \mathrm{O}_{3}$ are lower than the values reported by Corning Glass Works by $\sim 33 \%$. In addition SRTC determined the presence of $\mathrm{ZnO}$ and trace amounts of $\mathrm{Cl}(\sim 0.10 \pm 0.05 \mathrm{wt} \%)$ and $\mathrm{F}(-0.008 \pm 0.005 \mathrm{wt} \%)$. The presence of the $\mathrm{ZnO}$ impurity was ascertained from glasses that were dissolved in microwave Teflon ${ }^{\circledR}$ bombs. Therefore, the presence of the trace $\mathrm{ZnO}$ is not due to impurities in the dissolution vessel as observed when samples are dissolved in nickel or zirconia crucibles. ${ }^{23} \mathrm{The} \mathrm{Cl}$ and $\mathrm{F}$ analyses have large standard deviations since the values measured are close to the detection limits of the measurement technique.

The EA glass is homogeneous and suitable as a compositional, redox, and durability Standard Reference Material despite the minor differences between the SRTC and Corning Glass Works analyses for $\mathrm{La}_{2} \mathrm{O}_{3}$ and $\mathrm{ZnO}$. The presence of trace amounts of anions is not significant because the analytic determinations were so close to the detection limits of the instrumentation. 
Table 2. Replicate Analyses of the Environmental Assessment Glass

\begin{tabular}{|c|c|c|c|c|c|c|}
\hline & SAMPLE & AND ANAL & YTIC IDE & ITIFICATIC & & \\
\hline $\begin{array}{l}\text { OXIDE } \\
\text { WT\% }\end{array}$ & $\begin{array}{l}\text { 1-TOP-A } \\
2000074772 \\
2200074760 \\
1200080110 \\
2000080236\end{array}$ & $\begin{array}{l}\text { 2-TOP-A } \\
200074773 \\
200074761 \\
200080111 \\
m 200080128\end{array}$ & $\begin{array}{l}\text { 3-TOP-A } \\
200074774 \\
2000074762 \\
2200080112 \\
200080129\end{array}$ & $\begin{array}{l}\text { 1-MISC-A } \\
* 200074770 \\
200074763 \\
2000080113 \\
200088130 \\
* 2000\end{array}$ & $\begin{array}{l}2-\text { MISC } \\
200074777 \\
m 2000 / 7764 \\
m 200080114 \\
200080131\end{array}$ & $\begin{array}{l}\text { 3-MISC-A } \\
\$ 200074771 \\
\$ 200074765 \\
200080115 \\
\$ 200080132\end{array}$ \\
\hline $\mathrm{Al}_{2} \mathrm{O}_{3}$ & 3.58 & 3.67 & 3.77 & 3.54 & 3.80 & 3.46 \\
\hline $\mathrm{B}_{2} \mathrm{O}_{3}$ & 11.12 & 11.32 & 11.22 & 11.32 & 10.76 & 11.12 \\
\hline $\begin{array}{l}\mathrm{CaO} \\
\mathrm{Fe}_{2} \mathrm{O}_{3}\end{array}$ & $\begin{array}{l}1.20 \\
7.47\end{array}$ & $\begin{array}{l}1.22 \\
7.49\end{array}$ & $\begin{array}{l}1.22 \\
7.48\end{array}$ & $\begin{array}{l}1.23 \\
7.43\end{array}$ & $\begin{array}{l}1.15 \\
8.30\end{array}$ & $\begin{array}{l}1.20 \\
7.33\end{array}$ \\
\hline $\begin{array}{l}\mathrm{FeO} \\
\mathrm{K}_{2} \mathrm{O}\end{array}$ & $\begin{array}{l}1.59 \\
0.04\end{array}$ & $\begin{array}{l}1.57 \\
0.06\end{array}$ & $\begin{array}{l}1.69 \\
0.04\end{array}$ & $\begin{array}{l}1.60 \\
0.04\end{array}$ & $\begin{array}{l}1.61 \\
0.04\end{array}$ & $\begin{array}{l}1.50 \\
0.04\end{array}$ \\
\hline $\mathrm{La}_{2} \mathrm{O}_{3}$ & 0.27 & 0.28 & 0.28 & 0.27 & 0.26 & 0.26 \\
\hline $\mathrm{Li}_{2} \mathrm{O}$ & 4.19 & 4.24 & 4.28 & 4.19 & 4.02 & 4.13 \\
\hline $\begin{array}{l}\mathrm{MgO} \\
\mathrm{MnO} \\
\mathrm{Na}_{2} \mathrm{O}\end{array}$ & $\begin{array}{r}1.77 \\
1.35 \\
16.86\end{array}$ & $\begin{array}{r}1.79 \\
1.37 \\
17.03\end{array}$ & $\begin{array}{r}1.81 \\
1.38 \\
17.33\end{array}$ & $\begin{array}{r}1.78 \\
1.36 \\
16.90\end{array}$ & $\begin{array}{r}1.72 \\
1.32 \\
16.37\end{array}$ & $\begin{array}{r}1.76 \\
\because .33 \\
15.75\end{array}$ \\
\hline $\begin{array}{l}\mathrm{NiO} \\
\mathrm{SiO}_{2}\end{array}$ & $\begin{array}{r}0.52 \\
49.03\end{array}$ & $\begin{array}{r}0.52 \\
49.18\end{array}$ & $\begin{array}{r}0.54 \\
48.36\end{array}$ & $\begin{array}{r}0.54 \\
49.34\end{array}$ & $\begin{array}{r}0.50 \\
48.37\end{array}$ & $\begin{array}{r}0.50 \\
47.81\end{array}$ \\
\hline $\mathrm{TiO}_{2}$ & 0.64 & 0.65 & 0.66 & 0.64 & 0.62 & 0.63 \\
\hline $\begin{array}{l}\mathrm{ZnO} \\
\mathrm{ZrO}_{2}\end{array}$ & $\begin{array}{l}0.25 \\
0.48\end{array}$ & $\begin{array}{l}0.24 \\
0.48\end{array}$ & $\begin{array}{l}0.24 \\
0.46\end{array}$ & $\begin{array}{l}0.25 \\
0.44\end{array}$ & $\begin{array}{l}0.25 \\
0.70\end{array}$ & $\begin{array}{l}0.24 \\
0.42\end{array}$ \\
\hline $\begin{array}{l}\text { OXIDE } \\
\text { SUMS }\end{array}$ & 100.38 & 101.11 & 100.77 & 100.87 & 99.8 & 98.48 \\
\hline $\mathrm{Fe}^{2+} / \mathrm{Fe}^{3+}$ & 0.24 & 0.23 & 0.25 & 0.24 & 0.22 & 0.23 \\
\hline $\begin{array}{l}\text { ANION } \\
\text { WT\% }\end{array}$ & & & & & & \\
\hline $\begin{array}{l}\mathrm{Cl} \\
\mathrm{F}\end{array}$ & $\begin{array}{l}0.086 \\
0.006\end{array}$ & $\begin{array}{l}0.095 \\
0.005\end{array}$ & $\begin{array}{l}0.094 \\
0.013\end{array}$ & $\begin{array}{l}0.114 \\
0.003\end{array}$ & $\begin{array}{l}0.142 \\
0.005\end{array}$ & $\begin{array}{l}0.090 \\
0.004\end{array}$ \\
\hline
\end{tabular}


Table 2. Replicate Analyses of the Environmental Assessment Glass (Cont'd)

\begin{tabular}{|c|c|c|c|c|c|c|c|}
\hline \multirow{4}{*}{$\begin{array}{l}\text { OXIDE } \\
\text { WT\% }\end{array}$} & \multirow{4}{*}{$\begin{array}{l}\text { SAMPLE } \\
1-B-3 \\
* 200074778-8 \\
* 200074766 \\
* 200080116 \\
\$ 200080133\end{array}$} & \multicolumn{2}{|c|}{ AND ANALYTIC } & \multicolumn{2}{|c|}{ IDENTIFICATIONS } & \multirow{4}{*}{$\begin{array}{l}\text { STD } \\
\text { DEV }\end{array}$} & \multirow{4}{*}{$\begin{array}{l}\text { CORNING"S } \\
\text { GLASS } \\
\text { ANALYSIS }\end{array}$} \\
\hline & & 2-B-A & 2-M-1 & 2-M-3 & AVERAGE & & \\
\hline & & $\begin{array}{l}200074781 \\
200074767\end{array}$ & $\begin{array}{l}200074775 \\
200074768\end{array}$ & $\begin{array}{l}200074776 \\
1200074769\end{array}$ & & & \\
\hline & & $\begin{array}{l}200080117 \\
200080134\end{array}$ & $\begin{array}{l}\begin{array}{l}200080118 \\
200080135\end{array} \\
\$ 200\end{array}$ & $\begin{array}{l}\$ 200080119 \\
\$ 200080136\end{array}$ & & & \\
\hline $\mathrm{Al}_{2} \mathrm{O}_{3}$ & 3.43 & 3.55 & 3.55 & 3.64 & 3.60 & 0.12 & 3.70 \\
\hline $\mathrm{B}_{2} \mathrm{O}_{3}$ & 11.08 & 11.16 & 11.18 & 11.33 & 11.16 & 0.17 & 11.30 \\
\hline $\begin{array}{l}\mathrm{CaO} \\
\mathrm{Fe}_{2} \mathrm{O}_{3}\end{array}$ & $\begin{array}{l}1.25 \\
7.29\end{array}$ & $\begin{array}{l}1.15 \\
7.02\end{array}$ & $\begin{array}{l}1.24 \\
7.76\end{array}$ & $\begin{array}{l}1.48 \\
8.26\end{array}$ & $\begin{array}{l}1.23 \\
7.58\end{array}$ & $\begin{array}{l}0.09 \\
0.41\end{array}$ & $\begin{array}{l}1.12 \\
7.38\end{array}$ \\
\hline $\begin{array}{l}\mathrm{FeO} \\
\mathrm{K}_{2} \mathrm{O}\end{array}$ & $\begin{array}{l}1.63 \\
0.04\end{array}$ & $\begin{array}{l}1.61 \\
0.04\end{array}$ & $\begin{array}{l}1.51 \\
0.03\end{array}$ & $\begin{array}{l}1.60 \\
0.04\end{array}$ & $\begin{array}{l}1.59 \\
0.04\end{array}$ & $\begin{array}{l}0.06 \\
0.01\end{array}$ & $\begin{array}{l}1.45 \\
0.04\end{array}$ \\
\hline $\mathrm{La}_{2} \mathrm{O}_{3}$ & 0.30 & 0.28 & 0.28 & 0.33 & 0.28 & 0.02 & 0.42 \\
\hline $\mathrm{Li}_{2} \mathrm{O}$ & 4.17 & 4.03 & 4.25 & 4.57 & 4.21 & 0.15 & 4.26 \\
\hline $\begin{array}{l}\mathrm{MgO} \\
\mathrm{MnO} \\
\mathrm{Na}_{2} \mathrm{O}\end{array}$ & $\begin{array}{r}1.76 \\
1.34 \\
16.93\end{array}$ & $\begin{array}{r}1.71 \\
1.30 \\
16.45\end{array}$ & $\begin{array}{r}1.80 \\
1.38 \\
17.37\end{array}$ & $\begin{array}{c}1.97 \\
1.48 \\
16.85^{*}\end{array}$ & $\begin{array}{r}1.79 \\
1.36 \\
16.88\end{array}$ & $\begin{array}{l}0.07 \\
0.05 \\
0.32\end{array}$ & $\begin{array}{r}1.72 \\
1.34 \\
16.80\end{array}$ \\
\hline $\begin{array}{l}\mathrm{NiO} \\
\mathrm{SiO}_{2}\end{array}$ & $\begin{array}{r}0.52 \\
47.41\end{array}$ & $\begin{array}{r}0.51 \\
50.19\end{array}$ & $\begin{array}{r}0.54 \\
48.57\end{array}$ & $\begin{array}{r}0.60 \\
49.31\end{array}$ & $\begin{array}{r}0.53 \\
48.76\end{array}$ & $\begin{array}{l}0.03 \\
0.82\end{array}$ & $\begin{array}{r}0.57 \\
48.73\end{array}$ \\
\hline $\mathrm{TiO}_{2}$ & 0.66 & 0.63 & 0.67 & 0.72 & 0.65 & 0.03 & 0.70 \\
\hline $\begin{array}{l}\mathrm{ZnO} \\
\mathrm{ZrO}_{2}\end{array}$ & $\begin{array}{l}0.37 \\
0.44\end{array}$ & $\begin{array}{l}0.24 \\
0.42\end{array}$ & $\begin{array}{l}0.27 \\
0.46\end{array}$ & $\begin{array}{l}0.26 \\
0.48\end{array}$ & $\begin{array}{l}0.26 \\
0.48\end{array}$ & $\begin{array}{l}0.04 \\
0.08\end{array}$ & 0.46 \\
\hline OXIDE & 98.61 & 100.31 & 100.85 & 102.94 & 100.41 & & 100.00 \\
\hline $\mathrm{Fe}^{2+} / \mathrm{Fe}^{3+}$ & 0.25 & 0.26 & 0.22 & 0.22 & 0.23 & 0.01 & 0.22 \\
\hline \multicolumn{8}{|l|}{$\begin{array}{l}\text { ANION } \\
\text { WT\% }\end{array}$} \\
\hline $\begin{array}{l}\mathrm{Cl} \\
\mathrm{F}\end{array}$ & $\begin{array}{l}0.063 \\
0.005\end{array}$ & $\begin{array}{l}0.212 \\
0.010\end{array}$ & $\begin{array}{l}0.055 \\
0.017\end{array}$ & $\begin{array}{l}0.059 \\
0.010\end{array}$ & $\begin{array}{l}0.101 \\
0.008\end{array}$ & $\begin{array}{l}0.047 \\
0.005\end{array}$ & \\
\hline
\end{tabular}

this analysis had a significantly higher $\mathrm{Na}_{2} \mathrm{O}$ content than the remaining nine samples by ICP analysis and the Na concentration measured by AA was substituted and not bias corrected 


\section{Glass Viscosity Analyses}

The EA glass viscosity as a function of inverse temperature is given in Figure 1. The Fulcher equation of best fit to the measured data is

$$
\left.\log \eta(\text { poise })=-1.4913+2414.447 /\left(T{ }^{\circ} \mathrm{C}\right)-235.99\right)
$$

The EA glass viscosity calculated from Equation 1 at the DWPF melt temperature of $1150^{\circ} \mathrm{C}$ is 14.1 poise. The EA glass viscosity calculated from the DWPF processing algorithms 10 and the Corning Glass Works chemical analysis of the glass is 19.98 poise. The viscosity calculated using the SRS chemical analysis of the EA glass is 19.8 poise.

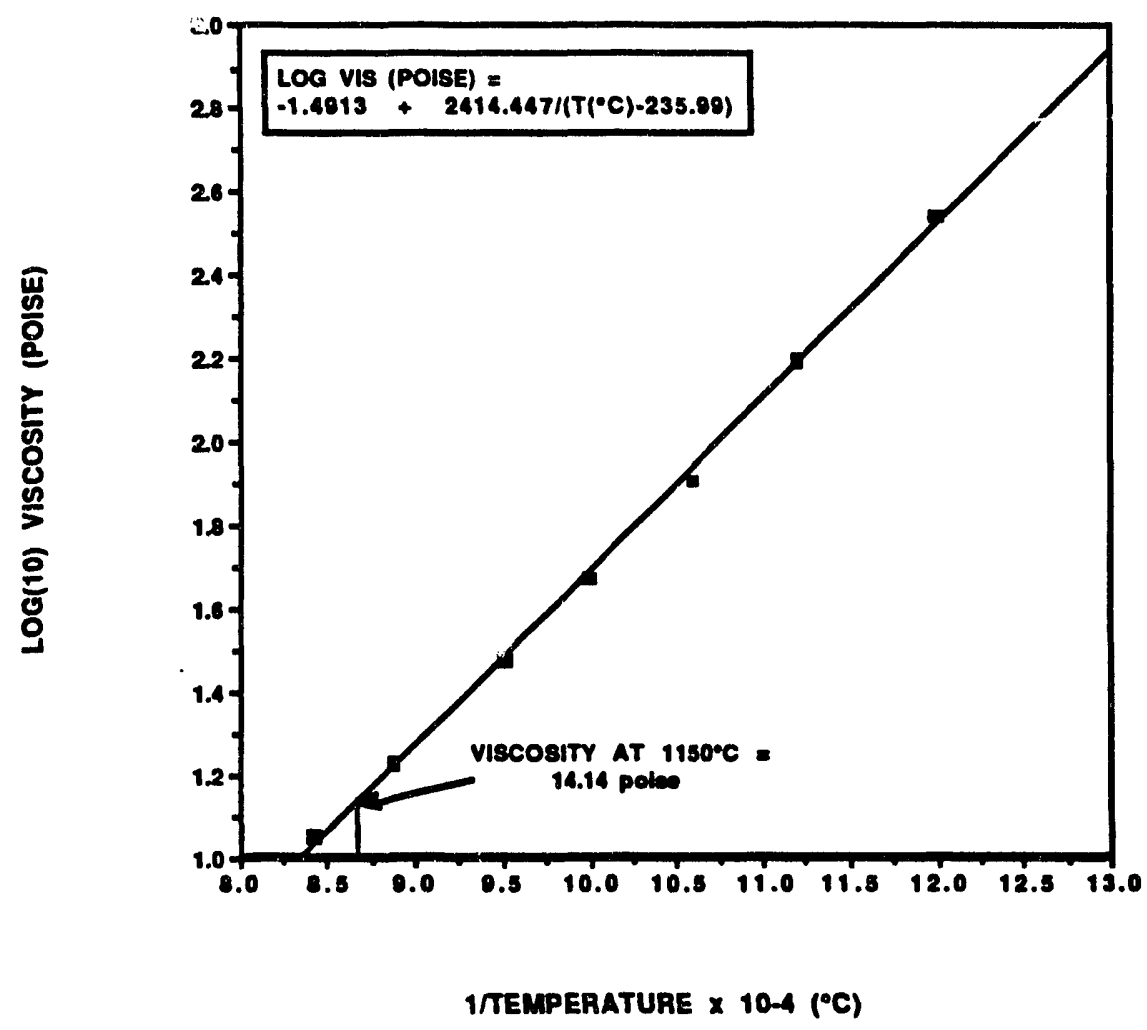

Figure 1. Fulcher plot of the viscosity of the EA glass. 


\section{Glass Homogeneity Analyses}

$\mathrm{X}$-ray Diffraction analysis indicated that the glass was $\mathrm{x}$-ray amorphous and contained no crystalline species. During optical microscopy, individual glass grains were determined to be green while others were amber in color. The different colored grain were hand separated and examined by SEM/EDAX. The light element EDAX detector indicated that the green grains appeared to have more carbon than the amber colored grains indicating that the green color was associated with more reduced glass. The green grains were evenly distributed throughout the glass indicating that the bulk redox was homogeneous as confirmed by the chemical analyses in Table 2.

\section{Glass Durability Analyses}

\section{Multielement Standard Analysis}

During PCT analysis, a multielement solution standard was used by each researcher to ensure that the solution analyses were accurate. Researcher one ran the multielement solution standard before leachate analysis began and after every 5 leachate samples in order to asses any short term bias in the leachate analyses due to instrumental drift (Appendix III). Analysis of the solution standard data indicated that there was less than $0.8 \mathrm{ppm}$ bias in the ICP analyses for $\mathrm{Na}, \mathrm{Li}, \mathrm{Al}, \mathrm{Fe}$, and $\mathrm{B}$, over $5 \mathrm{ppm}$ bias in the ICP analyses for $\mathrm{Si}$, and less than $0.4 \mathrm{ppm}$ oias in the Atomic Absorption (AA) analyses for $\mathrm{K}$ The data also indicated that there was $\sim 0.15 \mathrm{ppm}$ low bias in the $\mathrm{Na}$ determinations made by AA compared to the Na determinations by ICP analysis. Similar results were obtained by the other researchers. The instrumertal drift was considered insignificant.

\section{Standard Glass Analysis}

Historical control charting using PNL's Approved Reference Material (ARM-1) as the standard glass as the PCT standard glass did not indicate any significant bias in the elemental releases (in ppm) for all elements whether the test was performed in Teflon ${ }^{\circledR}$ or Parr 304L steel vessels (Table 3). All the standard glass elemental releases used in this study fell within one-sigma of the average elemental release for ARM-1 glass since May, 1989. Hence, no long term bias corrections were made to the EA glass solution data set. Varying dilution factors were used by each researcher but the solution data sets between researchers was in agreement. The ARM-1 measured pH values were slightly lower for researcher 2 (Table 3 ) as were the EA glass measured pH values.

\section{EA Glass Analysis}

The PCT leachate $\mathrm{pH}$ and leachate concentrations in ppm measured for the EA glass are given in Table 4. The leachates had to be diluted prior to analysis by ICP or AA in order to match the standardization concentrations of the respective instruments. Varying dilution factors were used by each researcher. The $1 \mathrm{H}$ values given for researcher 2 were bias corrected on a $1 /\left[\mathrm{H}^{+}\right]$linear basis based on the low value measured for the ARM-1 glass.

The leachate concentrations measured for the respective elements in the EA glass by the various researchers are in agreement. The data in the $22 \mathrm{~mL} 304 \mathrm{~L}$ Parr Bombs appear somewhat higher than the average leachate concentrations in the Teflon ${ }^{\circledR}$ vessels for the same researcher (Table 4). However, these values are within the average leachate concentrations measured by the other researchers in the Teflon ${ }^{\circledR}$ vessels. Varying the available head space in the $22 \mathrm{~mL}$ steel vessels appears to have no effect on leachate concentrations. 
Table 3. PCT Analysis of the ARM-1 Standard Glass

\begin{tabular}{|c|c|c|c|c|c|c|}
\hline SAMPLE & ADS \# & RESEARCHER & NOTEBOOK & $\begin{array}{c}\text { PCT } \\
\text { VERSION }\end{array}$ & $\begin{array}{l}\text { TYPE OF } \\
\text { VESSEL }\end{array}$ & $\begin{array}{l}\text { SIZE OF } \\
\text { VESSEL } \\
\text { (ML) }\end{array}$ \\
\hline $\begin{array}{l}\text { ARM-1-7-1 } \\
\text { ARM-1-7-2 } \\
\text { ARM-1-7-3 } \\
\text { ARM-1-7-AVG } \\
\% \text { STD DEV }\end{array}$ & $\begin{array}{l}200067152 \\
200067153 \\
200067156\end{array}$ & $\begin{array}{l}1 \\
1 \\
1\end{array}$ & $\begin{array}{l}\text { WSRC-NB-91-199 } \\
\text { WSRC-NB-91-199 } \\
\text { WSRC-NB-91-199 }\end{array}$ & $\begin{array}{l}3.0 \\
3.0 \\
3.0\end{array}$ & $\begin{array}{l}\text { TEFLON } \\
\text { TEFLON } \\
\text { TEFLON }\end{array}$ & $\begin{array}{l}60 \\
60 \\
60\end{array}$ \\
\hline $\begin{array}{l}\text { ARM-1-7-1 } \\
\text { ARM-1-7-2 } \\
\text { ARM-1-7-3 } \\
\text { ARM-1-7-AVG } \\
\text { \% STD DEV }\end{array}$ & $\begin{array}{l}200068356 \\
200068357 \\
200068358\end{array}$ & $\begin{array}{l}2 \\
2 \\
2\end{array}$ & $\begin{array}{l}\text { WSRC-NB-91-200 } \\
\text { WSRC-NB-91-201 } \\
\text { WSRC-NB-91-200 }\end{array}$ & $\begin{array}{l}3.0 \\
3.0 \\
3.0\end{array}$ & $\begin{array}{l}\text { TEFLON } \\
\text { TEFLON } \\
\text { TEFLON }\end{array}$ & $\begin{array}{l}60 \\
60 \\
60\end{array}$ \\
\hline $\begin{array}{l}\text { T-ARM-1-1 } \\
\text { T-ARM-1-2 } \\
\text { T-ARM-1-3 } \\
\text { T-ARM-1-AVG } \\
\text { \% STD DEV }\end{array}$ & $\begin{array}{l}200069692 \\
200069693 \\
200069693\end{array}$ & $\begin{array}{l}3 \\
3 \\
3\end{array}$ & $\begin{array}{l}\text { DPSTN } 4793 \\
\text { DPSTN-4793 } \\
\text { DPSTN }-4793\end{array}$ & $\begin{array}{l}3.0 \\
3.0 \\
3.0\end{array}$ & $\begin{array}{l}\text { TEFLON } \\
\text { TEFLON } \\
\text { TEFLON }\end{array}$ & $\begin{array}{l}60 \\
60 \\
60\end{array}$ \\
\hline $\begin{array}{l}\text { SS-ARM-1-1 } \\
\text { SS-ARM-1-2 } \\
\text { SS-ARM-1-3 } \\
\text { SS-ARM-1-AVG } \\
\text { \% STD DEV }\end{array}$ & $\begin{array}{l}200069695 \\
200069698 \\
200069699\end{array}$ & $\begin{array}{l}3 \\
3 \\
3\end{array}$ & $\begin{array}{l}\text { DPSTN }-4793 \\
\text { DPSTN } 4793 \\
\text { DPSTN }-4793\end{array}$ & $\begin{array}{l}3.0 \\
3.0 \\
3.0\end{array}$ & $\begin{array}{l}\text { PARR STEEL } \\
\text { PARR STEEL } \\
\text { PARR STEEL }\end{array}$ & $\begin{array}{l}22 \\
22 \\
22\end{array}$ \\
\hline $\begin{array}{l}\text { SS-ARM-1-1 } \\
\text { SS-ARM-1-2 } \\
\text { SS-ARM-1-AVG } \\
\% \text { STD DEV }\end{array}$ & $\begin{array}{l}200069701 \\
200069702\end{array}$ & $\begin{array}{l}3 \\
3\end{array}$ & $\begin{array}{l}\text { DPSTN }-4793 \\
\text { DPSTN } 4793\end{array}$ & $\begin{array}{l}3.0 \\
3.0\end{array}$ & $\begin{array}{l}\text { PARR STEEL } \\
\text { PARR STEEL }\end{array}$ & $\begin{array}{l}22 \\
22\end{array}$ \\
\hline
\end{tabular}


Table 3. PCT Analysis of the ARM-1 Standard Glass (Continued)

\begin{tabular}{|c|c|c|c|c|c|c|c|}
\hline \multirow[t]{2}{*}{ SAMPLE } & \multirow{2}{*}{$\begin{array}{l}\text { mL OF } \\
\text { LEACHANT }\end{array}$} & \multirow{2}{*}{$\begin{array}{l}\text { GMS OF } \\
\text { GLASS }\end{array}$} & \multirow{2}{*}{$\begin{array}{l}\text { MEASURED } \\
\text { pH }\end{array}$} & \multicolumn{3}{|c|}{ CONCENTRATIONS } & \multirow{2}{*}{$\begin{array}{l}(\mathrm{ppm}) \\
\mathrm{Si}\end{array}$} \\
\hline & & & & B & $\mathbf{L i}$ & $\mathrm{Na}^{*}$ & \\
\hline ARM-1-7-1 & 40 & 4.0 & 10.34 & 17.71 & 13.89 & 38.03 & 60.47 \\
\hline ARM-1-7-2 & 40 & 4.0 & 10.33 & 17.97 & 14.23 & 38.75 & 61.45 \\
\hline ARM-1-7-3 & 40 & 4.0 & 10.32 & 18.03 & 14.09 & 38.51 & 61.13 \\
\hline ARM-1-7-AVG & & & $\mathbf{i} 0.33$ & 17.90 & 14.07 & 38.43 & 61.02 \\
\hline$\%$ STD DEV & & & 0.01 & 0.14 & 0.14 & 0.30 & 0.41 \\
\hline ARM-1-7-1 & 35 & 3.5 & 9.38 & 18.11 & 14.31 & 39.95 & 60.71 \\
\hline ARM-1-7-2 & 35 & 3.5 & 9.40 & 18.32 & 14.45 & 37.17 & 60.67 \\
\hline ARM-1-7-3 & 35 & 3.5 & 9.35 & 17.12 & 13.46 & 34.83 & 57.18 \\
\hline ARM-1-7-AVG & & & 9.38 & 17.85 & 14.07 & 37.32 & 59.52 \\
\hline$\%$ STD DEV & & & 0.02 & 0.52 & 0.44 & 2.09 & 1.65 \\
\hline T.ARM-1-1 & 40 & 4.0 & 10.28 & 17.14 & 14.08 & 37.51 & 59.21 \\
\hline T-ARM-1-2 & 40 & 4.0 & 10.38 & 17.65 & 14.41 & 38.23 & 60.26 \\
\hline T-ARM-1-3 & 40 & 4.0 & 10.29 & 17.12 & 14.11 & 37.52 & 59.40 \\
\hline T-ARM-1-AVG & & & 10.32 & 17.31 & 14.20 & 37.75 & 59.62 \\
\hline \% STD DEV & & & 0.04 & 0.25 & 0.15 & 0.34 & 0.45 \\
\hline SS-ARM-1-1 & 19 & 1.9 & 10.38 & 18.71 & 15.01 & 39.84 & 62.66 \\
\hline SS-ARM-1-2 & 19 & 1.9 & 10.29 & 17.73 & 14.39 & 38.49 & 60.68 \\
\hline SS-ARM-1-3 & 19 & 1.9 & 10.29 & 19.50 & 15.25 & 40.87 & 63.38 \\
\hline SS-ARM-1-AVG & & & 10.32 & 18.65 & 14.88 & 39.73 & 62.24 \\
\hline$\%$ STD DEV & & & 0.04 & 0.72 & 0.36 & 0.97 & 1.14 \\
\hline SS-ARM-1-1 & 15 & 1.5 & 10.34 & 18.13 & 14.60 & 38.78 & 61.22 \\
\hline SS-ARM-1-2 & 15 & 1.5 & 10.38 & 19.78 & 15.65 & 41.62 & 64.44 \\
\hline SS-ARM-1-AVG & & & 10.36 & 18.96 & 15.13 & 40.20 & 62.83 \\
\hline \% STD DEV & & & 0.02 & 0.83 & 0.52 & 1.42 & 1.61 \\
\hline
\end{tabular}

* measured by ICP 
Table 4. PCT Analysis of the Environmental Assessment Glass

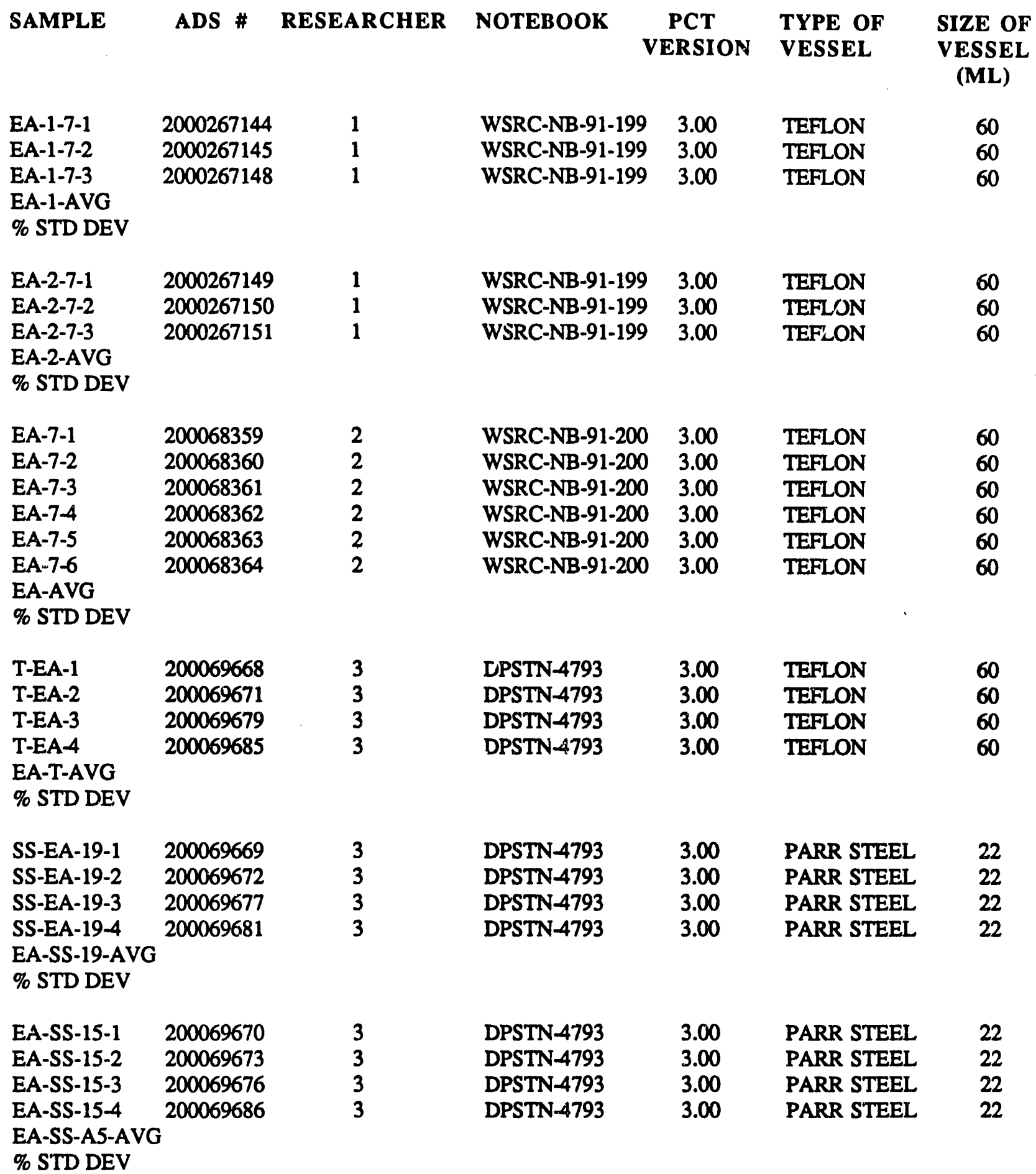


Table 4. PCT Analysis of the Environmental Assessment Glass (Continued).

\begin{tabular}{|c|c|c|c|c|c|c|c|}
\hline SAMPLE & $\mathbf{m L}$ OF & GMS OF & MEASURED & CON & CENTR & TIONS & (ppm) \\
\hline & LEACHANT & GLASS & pH & B & $\mathbf{L i}$ & $\mathrm{Na}^{*}$ & \\
\hline EA-1-7-1 & 40 & 4.00 & 11.80 & 567.96 & 210.71 & 1738.35 & 1048.41 \\
\hline EA-1-7-2 & 40 & 4.00 & 11.79 & 593.57 & 211.19 & 1819.70 & 1061.93 \\
\hline EA-1-7-3 & 40 & 4.00 & 11.80 & 605.97 & 212.86 & 1857.20 & 1070.91 \\
\hline EA-1-AVG & & & 11.80 & 589.17 & 2.11 .59 & 1805.08 & 1060.42 \\
\hline$\%$ STD DEV & & & 0.00 & 15.83 & 0.92 & 49.61 & 9.25 \\
\hline $\mathrm{EA}-2-7-1$ & 40 & 4.00 & 11.86 & 468.52 & 163.27 & 1380.80 & 780.29 \\
\hline EA-2-7-2 & 40 & 4.00 & 11.88 & 610.00 & 225.05 & 1854.87 & 1128.56 \\
\hline EA-2-7-3 & 40 & 4.00 & 11.88 & 523.05 & 171.77 & 1542.60 & 832.21 \\
\hline EA-2-AVG & & & 11.87 & 533.86 & 186.70 & 1592.76 & 913.69 \\
\hline \% STD DEV & & & 0.01 & 58.26 & 27.34 & 196.76 & 153.41 \\
\hline EA-7-1 & 35 & 3.50 & $12.01 * *$ & 609.42 & 192.06 & 1685.50 & 908.43 \\
\hline EA-7-2 & 35 & 3.50 & 12.01 & 615.07 & 187.92 & 1724.34 & 909.33 \\
\hline EA-7-3 & 35 & 3.50 & 12.01 & 634.81 & 195.74 & 1770.69 & 938.30 \\
\hline EA-7-4 & 35 & 3.50 & 12.01 & 638.54 & 204.01 & 1771.35 & 956.44 \\
\hline EA-7-5 & 35 & 3.50 & 12.01 & 649.05 & 208.11 & 1789.02 & 965.06 \\
\hline EA-7-6 & 35 & 3.50 & 12.01 & 584.70 & 186.73 & 1644.01 & 892.60 \\
\hline EA-AVG & & & 12.01 & 621.93 & 195.76 & 1730.82 & 928.36 \\
\hline \% STD DEV & & & 0.00 & 21.47 & 7.93 & 52.04 & 26.68 \\
\hline T-EA-1 & 40 & 4.00 & 11.88 & 499.85 & 162.08 & 1429.74 & 763.41 \\
\hline T-EA-2 & 40 & 4.00 & 11.88 & 493.34 & 161.27 & 1408.62 & 746.67 \\
\hline T-EA-3 & 40 & 4.00 & 11.89 & 517.52 & 167.81 & 1480.44 & 782.22 \\
\hline T-EA-4 & 40 & 4.00 & 11.89 & 560.09 & 183.35 & 1572.63 & 825.27 \\
\hline EA-T-AVG & & & 11.89 & 517.70 & 168.63 & 1472.86 & 779.39 \\
\hline \% STD DEV & & & $\therefore 0.00$ & 26.02 & 8.87 & 63.24 & 29.32 \\
\hline SS-EA-19-1 & 19 & 1.90 & 11.92 & 577.41 & 180.78 & 1633.95 & '/98.81 \\
\hline SS-EA-19-2 & 19 & 1.90 & 11.90 & 566.13 & 177.48 & 1604.19 & 791.43 \\
\hline SS-EA-19-3 & 19 & 1.90 & 11.95 & 576.06 & 180.48 & 1635.24 & 794.04 \\
\hline SS-EA-19-4 & 19 & 1.90 & 11.91 & 584.31 & 183.60 & 1650.21 & 803.25 \\
\hline EA-SS-19-AVG & & & 11.92 & 575.98 & 180.59 & 1630.90 & 796.88 \\
\hline \% STD DEV & & & 0.02 & 6.49 & 2.17 & 16.69 & 4.53 \\
\hline EA-SS-15-1 & 15 & 1.50 & 11.98 & 596.10 & 190.26 & 1670.40 & 846.96 \\
\hline EA-SS-15-2 & 15 & 1.50 & 11.92 & 601.41 & 191.52 & 1692.06 & 852.09 \\
\hline EA-SS-15-3 & 15 & 1.50 & 11.93 & 587.04 & 196.68 & 1640.88 & 848.55 \\
\hline EA-SS-15-4 & 15 & 1.50 & 11.95 & 572.67 & 193.11 & 1606.35 & 830.64 \\
\hline EA-SS-A5-AVG & & & 11.95 & 589.31 & 192.89 & 1052.42 & 844.56 \\
\hline \% STD DEV & & & 0.02 & 10.89 & 2.41 & 32.21 & 8.25 \\
\hline
\end{tabular}

* measured by ICP

** bias corrected based on ARM-1 pH measurements 
Table 5. PCT Analysis of the Environmental Assessment Glass.

\begin{tabular}{|c|c|c|c|c|c|c|c|c|c|}
\hline \multirow[t]{2}{*}{ SAMPLE } & \multicolumn{4}{|c|}{ NORMALIZED MASS LOSS } & \multicolumn{3}{|c|}{ LOG NORMALIZED } & MASS LOSS & \multirow{2}{*}{$\begin{array}{c}\Delta \mathbf{G}_{\text {hyd }} \\
\text { (Kcal/ } \\
\text { mole)* }\end{array}$} \\
\hline & B & $\mathbf{L i}^{(\mathrm{g}}$ & & $\mathbf{S i}$ & & & & Si & \\
\hline EA-1-7-1 & 16.18 & 10.64 & 13.95 & 4.60 & 1.21 & 1.03 & 1.14 & 0.66 & -13.68 \\
\hline EA-1-7-2 & 16.91 & 10.67 & 14.60 & 4.66 & 1.23 & 1.03 & 1.16 & 0.67 & -13.65 \\
\hline EA-1-7-3 & 17.26 & 10.75 & 14.91 & 4.70 & 1.24 & 1.03 & 1.17 & 0.67 & -13.68 \\
\hline EA-1-AVG & 16.79 & 10.69 & 14.49 & 4.66 & 1.22 & 1.03 & 1.16 & 0.67 & -13.67 \\
\hline \% STD DEV & 0.45 & 0.05 & 0.40 & 0.04 & 0.01 & 0.00 & 0.01 & 0.00 & \\
\hline EA-2-7-1 & 13.35 & 8.25 & 11.08 & 3.43 & 1.13 & 0.92 & 1.04 & 0.53 & -13.89 \\
\hline EA-2-7-2 & 17.38 & 11.37 & 14.89 & 4.95 & 1.24 & 1.06 & 1.17 & 0.69 & -13.96 \\
\hline EA-2-7-3 & 14.90 & 8.68 & 12.38 & 3.65 & 1.17 & 0.94 & 1.09 & 0.56 & -13.96 \\
\hline EA-2-AVG & 15.21 & 9.43 & 12.78 & 4.01 & 1.18 & 0.97 & 1.10 & 0.60 & -13.93 \\
\hline \% STD DEV & 1.66 & 1.38 & 1.58 & 0.67 & 0.05 & 0.06 & 0.05 & 0.07 & \\
\hline EA-7-1 & 17.36 & 9.70 & 13.53 & 3.99 & 1.24 & 0.99 & 1.13 & 0.60 & -14.42 \\
\hline EA-7-2 & 17.52 & 9.49 & 13.84 & 3.99 & 1.24 & 0.98 & 1.14 & 0.60 & -14.42 \\
\hline EA-7-3 & 18.09 & 9.89 & 14.21 & 4.12 & 1.26 & 1.00 & 1.15 & 0.61 & -14.42 \\
\hline EA-7-4 & 18.19 & 10.30 & 14.22 & 4.20 & 1.26 & 1.01 & 1.15 & 0.62 & -14.42 \\
\hline EA-7-5 & 18.49 & 10.51 & 14.36 & 4.24 & 1.27 & 1.02 & 1.16 & 0.63 & -14.42 \\
\hline EA-7-6 & 16.66 & 9.43 & 13.19 & 3.92 & 1.22 & 0.97 & 1.12 & 0.59 & -14.42 \\
\hline EA-AVG & 17.72 & 9.89 & 13.89 & 4.08 & 1.25 & 0.99 & 1.14 & 0.61 & -14.42 \\
\hline \% STD DEV & 0.61 & 0.40 & 0.42 & 0.12 & 0.02 & 0.02 & 0.01 & 0.01 & \\
\hline T-EA-1 & 14.24 & 8.19 & 11.47 & 3.35 & 1.15 & 0.91 & 1.06 & 0.53 & -13.96 \\
\hline T-EA-2 & 14.06 & 8.14 & 11.31 & 3.28 & 1.15 & 0.91 & 1.05 & 0.52 & -13.96 \\
\hline T-EA-3 & 14.74 & 8.48 & 11.88 & 3.43 & 1.17 & 0.93 & 1.07 & 0.54 & -13.99 \\
\hline T-EA-4 & 15.96 & 9.26 & 12.62 & 3.62 & 1.20 & 0.97 & 1.10 & 0.56 & -13.99 \\
\hline EA-T-AVG & 14.75 & 8.52 & $1: .82$ & 3.42 & 1.17 & 0.93 & 1.07 & 0.53 & -13.97 \\
\hline \% STD DEV & 0.74 & 0.45 & 0.51 & 0.13 & 0.02 & 0.02 & 0.02 & 0.02 & \\
\hline SS-EA-19-1 & 16.45 & 9.13 & 13.11 & 3.51 & 1.22 & 0.96 & 1.12 & 0.54 & -14.10 \\
\hline SS-EA-19-2 & 16.13 & 8.96 & 12.87 & 3.47 & 1.21 & 0.95 & 1.11 & 0.54 & -14.03 \\
\hline SS-EA-19-3 & 16.41 & 9.12 & 13.12 & 3.49 & 1.22 & 0.96 & 1.12 & 0.54 & -14.20 \\
\hline SS-EA-19-4 & 16.65 & 9.27 & 13.24 & 3.53 & 1.22 & 0.97 & 1.12 & 0.55 & -14.06 \\
\hline EA-SS-19-AVG & 16.41 & 9.12 & 13.09 & 3.50 & 1.22 & 0.96 & 1.12 & 0.54 & -14.10 \\
\hline \% STD DEV & 0.18 & 0.11 & 0.13 & 0.02 & 0.00 & 0.01 & 0.00 & 0.00 & \\
\hline EA-SS-15-1 & 16.98 & 9.61 & 13.41 & 3.72 & 1.23 & 0.98 & 1.13 & 0.57 & -14.31 \\
\hline EA-SS-15-2 & 17.13 & 9.67 & 13.58 & 3.74 & 1.23 & 0.99 & 1.13 & 0.57 & -14.10 \\
\hline EA-SS-15-3 & 16.72 & 9.93 & 13.17 & 3.72 & 1.22 & 1.00 & 1.12 & 0.57 & -14.13 \\
\hline EA-SS-15-4 & 16.32 & 9.75 & 12.89 & 3.65 & 1.21 & 0.99 & 1.11 & 0.56 & -14.20 \\
\hline EA-SS-A5-AVG & 16.79 & 9.74 & 13.26 & 3.71 & 1.22 & 0.99 & 1.12 & 0.57 & -14.19 \\
\hline$\%$ STD DEV & -0.31 & 0.12 & 0.26 & 0.04 & 0.01 & 0.01 & 0.01 & 0.00 & \\
\hline
\end{tabular}

${ }^{*} \Delta \mathrm{G}_{\text {hyd }}$ without $\mathrm{pH}$ correction is $-7.28 \mathrm{Kcal} / \mathrm{mole}$ based on CGW analysis in Table 2 
The leachate concentrations are reported as normalized elemental losses, $\mathrm{NC}_{\mathrm{i}}$, released from the glass in grams of glass per $\mathrm{L}$ of leachant. This has the advantage that the release concentrations in parts per million are normalized by the weight fraction of that element present in the glass. The

normalized release, $\mathrm{NC}_{\mathrm{i}}$, is a function of (1) the mass fraction of that element in the glass, (2) the exposed surface area of the glass, and (3) the leachate volume. Since the latter two are held constant, the normalized release is expressed as:

$$
N C_{i}=\frac{C_{i}}{F_{i}}
$$

where

$$
\begin{aligned}
N C_{i} & =\text { normalized release }\left(g_{\text {glass }} / L_{\text {leachant }}\right) \\
C_{i} & =\text { mass of element } " \mathrm{i} " \text { in the solution }\left(g_{j} / \mathrm{m}^{3}\right) \\
F_{i} & =\text { fraction of element } " \mathrm{i} \text { " in the glass }\left(\mathrm{g}_{\mathrm{i}} / \mathrm{g}_{\text {glass }}\right)
\end{aligned}
$$

The units of $\mathrm{NC}_{\mathrm{i}}$ are normally expressed as grams of glass dissolved per liter of leachant. The normalized releases were calculated using the Corning analyzed glass composition given in Table 2. The normalized releases were calculated in grams of glass based on $\mathrm{B}, \mathrm{Li}, \mathrm{Si}, \mathrm{Na}$, and $\mathrm{K}$ leached per liter of leachate $(\mathrm{g} / \mathrm{L})$ as given in Equation 1. The calculation of $\mathrm{NC}_{\mathrm{i}}$ and $\log \mathrm{NC}_{\mathrm{i}}$ are given in Table 5.

\section{CONCLUSIONS}

The chemical analysis of the EA glass indicates that the glass is within the target composition specified and has an $\mathrm{Fe}^{2+} / \mathrm{Fe}^{3+}$ ratio of 0.23 compared to Corning Glass Works' value of 0.22 . The chemical analyses in this study verify the Corning Glass Works analysis except for the lower concentration of $\mathrm{La}_{2} \mathrm{O}_{3}$ measured in this study. In addition, minor amounts of $\mathrm{ZnO}, \mathrm{Cl}$ and $\mathrm{F}$ were detected in the glass. The presence of trace amounts of anions is not considered significant because the analytic determinations were so close to the detection limits of the measurement technique.

The chemical composition of the 1000 pounds of glass was determined to be homogeneous. The glass was $\mathrm{x}$-ray amorphous and found to be composed of individual grains which varied in redox but were homogeneously distributed. The PCT leachate data of the EA glass appears to be internally consistent. No significant long term or short term instrumental analytic bias was observed. The leachate results were comparable in Teflon ${ }^{\circledR}$ and in Parr 304L stainless steel vessels with a smooth internal finish. The EA glass fabricated by Corning Glass Works is suitable as a composition, redox, and durability Standard Reference Material.

\section{ACKNOWLEDGEMENT}

The authors would like to acknowledge the efforts of C.J. Coleman of SRTC in verifying the EA glass composition. 
This page intentionally left blank.

-24 - 


\section{REFERENCES}

1. Waste Acceptance Preliminary Specifications for the Defense Waste Processing Facility High-Level Waste Form, U. S. Department of Energy, Office of Civilian Radioactive Waste Management, USDOE Document OGR/B-8, Washington, DC (1988).

2. C. M. Jantzen and N. E. Bibler, "Product Consistency Test (PCT) and Test Protocol," USDOE Report DPST-87-575, E.I duPont deNemours \& Co, Savannah River Laboratory, Aiken, SC (1987).

3. C. M. Jantzen and N. E. Bibler, "Nuclear Waste Product Consistency Test (PCT) -Version 3.0," USDOE Report WSRC-TR-90-539, Rev. 1, Westinghouse Savannah River Co., Savannah River Laboratory, Aiken, SC (November, 1990).

4. N.E. Bibler and C.M. Jantzen, "The Product Consistency Test and Its Role in the Waste Acceptance Process for DWPF Glass," Waste Management '89, Volume I, R.G. Post and M.E. Wacks (Eds.), University of Arizona, 743-749 (1989).

5. C.M. Jantzen and N.E. Bibler, "The Product Consistency Test for the DWPF Wasteform," Requiremer.is for Waste Acceptance and Quality Control, Proceedings of the 2nd International Seminar on Radioactive Waste Products, E. Warnecke, R. Odoj, and R. Simon (Eds.), Kernforschunganlanger (KFA) Research Center, Julich, Federal Republic of Germany, 609-622 (1990).

6. G. F. Piepel, T. E. Jones, D. L. Eggett, G. B. Mellinger, “Product Consistency Test Round Robin Conducted by the Materials Characterization Center Summary Report," USDOE Report PNL-6967, Materials Characterization Center, Battelle Pacific Northwest Laboratories, Richland, WA (1989).

7. N. E. Bibler and J. K. Bates, "Product Consistency Leach Tests of Savannah River Site Radioactive Waste Glasses," Scientific Basis for Nuclear Waste Management, XIII, V. M. Oversby and P. W. Brown (Eds.), Materials Research Society, Pittsburgh, PA, 327-338 (1990).

8. U.S. Department of Energy, "Environmental Assessment Waste Form Selection for SRP High-Level Waste," U.S. DOE Report DOE-EA-0179 (July, 1982).

9. C.M. Jantzen, "Relationship of Glass Composition to Giass Viscosity, Resistivity, Liquidus Temperature, and Durability: First Principles ProcessProduct Models for Vitrification of Nuclear Waste," Proceedings of the 5th International Symposium on Ceramics in Nuclear Waste Management, G.G. Wicks, D.F. Bickford, and R. Burnell (Eds.), American Ceramic Society, Westerville, OH, 37-51 (1991).

10. M. J. Plodinec, "Factors Affecting the Iron Oxidation State and Foaming in SRP Waste Glass," Proceedings of the Symposium on High Temperature Materials Chemistry, D. D. Cubicciotti and D. L. Hildebrand (Eds.), The Electrochemical Society, Pennington, New Jersey, 201-209 (1982). 
11. C. M. Jantzen, D. F. Bickford and D. G. Karraker, "Time-TemperatureTransformation Kinetics in SRL Waste Glass," Advances in Ceramics, V.8 G. G. Wicks and W. A. Ross (Eds.), 30-38 (1984).

12. D. F. Bickford and R. B. Diemer, Jr., "Redox Control of Electric Melters with Complex Feed Compositions, Part I. Analytical Methods and Models," L. NonCryst. Solids. 84, 276-284 (1986).

13. D. F. Bickford and R. B. Diemer, Jr., D. C. Iverson "Redox Control of Electric Melters with Complex Feed Compositions, Part II. Preliminary Limits for Radioactive Waste Melters," L.Non-Cryst.Solids, 84, 285-291 (1986).

14. D. F. Bickford, R. C. Probst, and M. J. Plodinec, "Control of Radioactive Waste Glass Melters: Part III. Glass Electrical Stability," Advances in the Fusion of Glass, D. F. Bickford, et. al. (Eds.), The American Ceramic Society, Westerville, $\mathrm{OH}, 19.1-19.17$ (1988).

15. L. R. Bunnell, "Laboratory Work in Support of West Valley Glass Development," USDOE Report PNL-6539, Battelle Pacific Northwest Laboratory, Richland, WA,(May, 1988).

16. C.M. Jantzen and M.J. Plodinec, "Composition and Redox Control of Waste Glasses: Recommendation for Process Control Limit," USDOE Report DPST-86773, E.I. duPont deNemours \& Co., Savannah River Laboratory, Aiken, SC (November, 1986).

17. C.M. Jantzen, "Verification and Standardization of Glass Redox Measurement for DWPF," USDOE Report DPST-89-222, E.I. duPont deNemours \& Co., Savannah River Laboratory, Aiken, SC (January, 1989).

18. G.F. Piepel and G.B. Mellinger, "Statistical Aspects of Compliance with the WAPS Radionuclide Release Specification," Proceedings of the 4th International Symposium on Ceramics in Nuclear Waste Management, III, G.B. Mellinger (Ed.), Ceramic Transactions, V. 9, American Ceramic Society, Westerville, OH, 483-494 (1990).

19. C.M. Jantzen, "Verification of Glass Composition and Strategy for SGM and DWPF Glass Composition Determination," USDOE Report DPST-86-708, E.I. duPont deNemours \& Co., Savvanah River Laboratory, Aiken, SC (March 30, 1987).

20. C.M. Jantzen, "Composition of Linde IE95 (AW500) Zeolite Fraction of Sludge," USDOE Report DPST'-88-623, E.I. duPont deNemours \& Co., Savannah River Laboratory, Aiken, SC (June, 1988).

21. E.W. Baumann, "Colorimetric Determination of Iron (II) and Iron (III) in Glass," Analyst, v. 117, 913-916 (1992).

22. Waste Form Compliance Plan for the Defense Waste Processing Facility, Revision 0, USDOE Document WSRC-SW4-6, Westinghouse Savannah River Company, Aiken, SC, March 1990. 
23. T.A. Policke, "Demonstration of Method DPST-88-272, Sodium Peroxide Fusion Dissolution of Sludge, Glass, and Melter Feed for Elemental Analysis," USDOE Report WSRC-TR-92-313, Westinghouse Savannah River Company, Aiken, SC (June, 1992). 
This page intentionally left blank.

- 28 - 


\title{
APPENDIX I Corning Glass Works Chemical Analysis of EA Glass
}

\author{
LABORATORY ANALYSIS REPORT
}

CELS Client No.: 11988-036

Exhibit A: Quantitative Chemical Analysis

Sample Description: 1000 1b. Standard

Sample 1

Dissolution 1 Dissolution 2 Dissolution 3 Read 1 Read 2 Read 1 Read 2 Read 1 Read 2

\begin{tabular}{lrlllll}
\hline Al203 & 3.75 & 3.72 & 3.72 & 3.72 & 3.69 & 3.69 \\
B2O3 & 11.1 & 11.2 & 11.2 & 11.2 & 11.3 & 11.4 \\
$\mathrm{CaO}$ & 1.12 & 1.12 & 1.12 & 1.12 & 1.11 & 1.11 \\
$\mathrm{Fe} 203$ & 7.39 & 7.38 & 7.52 & 7.52 & 7.36 & 7.31 \\
$\mathrm{FeO}$ & 1.45 & 1.46 & 1.36 & 1.36 & 1.47 & 1.48 \\
$\mathrm{K2O}$ & 0.04 & 0.04 & 0.04 & 0.04 & 0.04 & 0.04 \\
$\mathrm{La203}$ & 0.42 & 0.42 & 0.42 & 0.42 & 0.42 & 0.42 \\
$\mathrm{Li20}$ & 4.28 & 4.29 & 4.25 & 4.24 & 4.26 & 4.26 \\
$\mathrm{MgO}$ & 1.74 & 1.72 & 1.72 & 1.72 & 1.72 & 1.71 \\
$\mathrm{MnO}$ & 1.35 & 1.34 & 1.35 & 1.35 & 1.35 & 1.34 \\
$\mathrm{Na20}$ & 16.8 & 16.8 & 16.8 & 16.8 & 16.8 & 16.8 \\
$\mathrm{NiO}$ & 0.58 & 0.57 & 0.57 & 0.57 & 0.57 & 0.57 \\
$\mathrm{SiO2}$ & 49.3 & 48.9 & 49.0 & 49.0 & 48.6 & 48.5 \\
$\mathrm{TiO2}$ & 0.71 & 0.70 & 0.70 & 0.70 & 0.70 & 0.69 \\
$\mathrm{ZrO2}$ & 0.46 & 0.46 & 0.48 & 0.47 & 0.46 & 0.46 \\
$\mathrm{TOtal}$ & 100.49 & 100.12 & 100.25 & 100.23 & 99.85 & 99.78 \\
& & & & & & \\
$\mathrm{Fe203}(\mathrm{TOT})$ & 9.01 & 9.01 & 9.04 & 9.04 & 9.00 & 8.96 \\
$\mathrm{Fe}(\mathrm{TOT})$ & 6.30 & 6.30 & 6.32 & 6.32 & 6.29 & 6.26 \\
$\mathrm{FeO}$ & 1.45 & 1.46 & 1.36 & 1.36 & 1.47 & 1.48 \\
$\mathrm{Fe}(+2)$ & 1.13 & 1.13 & 1.06 & 1.06 & 1.14 & 1.15 \\
$\mathrm{Fe}(+3)$ & 5.17 & 5.16 & 5.26 & 5.26 & 5.15 & 5.11 \\
$\mathrm{Fe} 203(+3)$ & 7.39 & 7.38 & 7.52 & 7.52 & 7.36 & 7.31 \\
$\mathrm{Fe+2/Fe+3}$ & 0.22 & 0.22 & 0.20 & 0.20 & 0.22 & 0.22 \\
& & & & & &
\end{tabular}




\section{LABORATORY ANALYSIS REPORT}

CELS Client No.: 11988-036

Exhibit A: Quantitative Chemical Analysis

Sample Description: 1000 lb. Standard

Sample 2

Dissolution 1 Dissolution 2 Dissolution 3 Read 1 Read 2 Read 1 Read 2 Read 1 Read 2

$\begin{array}{lrrrrrr}\text { Al203 } & 3.67 & 3.73 & 3.72 & 3.69 & 3.69 & 3.70 \\ \text { B2O3 } & 11.2 & 11.3 & 11.2 & 11.3 & 11.4 & 11.3 \\ \text { CaO } & 1.11 & 1.12 & 1.12 & 1.11 & 1.12 & 1.12 \\ \text { Fe203 } & 7.27 & 7.35 & 7.39 & 7.36 & 7.40 & 7.40 \\ \text { FeO } & 1.47 & 1.48 & 1.48 & 1.50 & 1.48 & 1.49 \\ \text { K2O } & 0.04 & 0.04 & 0.04 & 0.04 & 0.04 & 0.04 \\ \text { La203 } & 0.42 & 0.42 & 0.42 & 0.42 & 0.41 & 0.42 \\ \text { Li20 } & 4.27 & 4.28 & 4.26 & 4.25 & 4.27 & 4.24 \\ \text { MgO } & 1.71 & 1.71 & 1.71 & 1.71 & 1.72 & 1.72 \\ \text { MnO } & 1.33 & 1.32 & 1.34 & 1.33 & 1.35 & 1.35 \\ \text { Na2O } & 16.8 & 16.8 & 16.8 & 16.8 & 16.8 & 16.8 \\ \text { NiO } & 0.56 & 0.56 & 0.57 & 0.57 & 0.57 & 0.57 \\ \text { SiO2 } & 48.7 & 48.8 & 48.8 & 48.5 & 48.7 & 48.8 \\ \text { TiO2 } & 0.69 & 0.70 & 0.70 & 0.70 & 0.70 & 0.70 \\ \text { ZrO2 } & 0.47 & 0.47 & 0.48 & 0.47 & 0.46 & 0.47 \\ \text { Tota1 } & 99.71 & 100.08 & 100.03 & 99.75 & 100.11 & 100.12 \\ & & & & & & \\ \text { Fe2O3 (TOT) } & 8.91 & 9.00 & 9.04 & 9.03 & 9.05 & 9.06 \\ \text { FeO(TOT) } & 6.23 & 6.29 & 6.32 & 6.31 & 6.33 & 6.33 \\ \text { FeO } & 1.47 & 1.48 & 1.48 & 1.50 & 1.48 & 1.49 \\ \text { Fe(+2) } & 1.14 & 1.15 & 1.15 & 1.17 & 1.15 & 1.16 \\ \text { Fe(+3) } & 5.09 & 5.14 & 5.17 & 5.15 & 5.18 & 5.18 \\ \text { Fe2O3(+3) } & 7.27 & 7.35 & 7.39 & 7.36 & 7.40 & 7.40 \\ \text { Fe+2/Fe+3 } & 0.22 & 0.22 & 0.22 & 0.23 & 0.22 & 0.22\end{array}$




\section{LABORATORY ANALYSIS REPORT}

CELS Client No.: 11988-036

Exhibit A: Quantitative Chemical Analysis

Sample Description: 1000 1b. Standard

Sample 3

Dissolution 1 Dissolution 2 Dissolution 3 Read 1 Read 2 Read 1 Read 2 Read 1 Read 2

\begin{tabular}{|c|c|c|c|c|c|c|}
\hline $\begin{array}{l}\mathrm{A} 1203 \\
\mathrm{~B} 203 \\
\mathrm{C} O \\
\mathrm{Fe} 203 \\
\mathrm{FeO} \\
\mathrm{K} 2 \mathrm{O} \\
\mathrm{La2O3} \\
\mathrm{Li} 20 \\
\mathrm{MgO} \\
\mathrm{MnO} \\
\mathrm{Na2O} \\
\mathrm{NiO} \\
\mathrm{SiO} 2 \\
\mathrm{TiO} \\
\mathrm{ZrO} 2\end{array}$ & $\begin{array}{l}3.66 \\
11.3 \\
1.10 \\
7.21 \\
1.47 \\
0.04 \\
0.42 \\
4.27 \\
1.69 \\
1.32 \\
16.8 \\
0.56 \\
48.0 \\
0.69 \\
0.44\end{array}$ & $\begin{array}{l}3.70 \\
11.3 \\
1.12 \\
7.27 \\
1.47 \\
0.04 \\
0.42 \\
4.28 \\
1.70 \\
1.33 \\
16.8 \\
0.57 \\
48.3 \\
0.69 \\
0.45\end{array}$ & $\begin{array}{l}3.68 \\
11.2 \\
1.11 \\
7.44 \\
1.38 \\
0.04 \\
0.41 \\
4.25 \\
1.71 \\
1.34 \\
16.9 \\
0.57 \\
48.6 \\
0.69 \\
0.45\end{array}$ & $\begin{array}{l}3.72 \\
11.3 \\
1.12 \\
7.50 \\
1.38 \\
0.04 \\
0.41 \\
4.25 \\
1.72 \\
1.35 \\
16.99 \\
0.57 \\
48.9 \\
0.70 \\
0.45\end{array}$ & $\begin{array}{l}3.73 \\
11.4 \\
1.12 \\
7.43 \\
1.43 \\
0.04 \\
0.42 \\
4.27 \\
1.73 \\
1.35 \\
16.8 \\
0.57 \\
49.3 \\
0.70 \\
0.44\end{array}$ & $\begin{array}{l}3.71 \\
11.4 \\
1.12 \\
7.41 \\
1.43 \\
0.04 \\
0.42 \\
4.25 \\
1.72 \\
1.35 \\
16.7 \\
0.57 \\
49.1 \\
0.70 \\
0.44\end{array}$ \\
\hline Total & 98.97 & 99.44 & 99.77 & 100.31 & 100.73 & 100.36 \\
\hline $\begin{array}{l}\mathrm{Fe} 203 \text { ( TOT) } \\
\mathrm{Fe}(\mathrm{TOT})\end{array}$ & $\begin{array}{l}8.85 \\
6.19\end{array}$ & $\begin{array}{l}8.91 \\
6.23\end{array}$ & $\begin{array}{l}8.98 \\
6.28\end{array}$ & $\begin{array}{l}9.04 \\
6.32\end{array}$ & $\begin{array}{l}9.02 \\
6.30\end{array}$ & $\begin{array}{l}9.00 \\
6.29\end{array}$ \\
\hline $\begin{array}{l}\text { FeO } \\
\mathrm{Fe}(+2)\end{array}$ & $\begin{array}{l}1.47 \\
1.14\end{array}$ & $\begin{array}{l}1.47 \\
1.14\end{array}$ & $\begin{array}{l}1.38 \\
1.07\end{array}$ & $\begin{array}{l}1.38 \\
1.07\end{array}$ & $\begin{array}{l}1.43 \\
1.11\end{array}$ & $\begin{array}{l}1.43 \\
1.11\end{array}$ \\
\hline $\begin{array}{l}\mathrm{Fe}(+3) \\
\mathrm{Fe} 203(+3)\end{array}$ & $\begin{array}{l}5.04 \\
7.21\end{array}$ & $\begin{array}{l}5.09 \\
7.27\end{array}$ & $\begin{array}{l}5.20 \\
7.44\end{array}$ & $\begin{array}{l}5.25 \\
7.50\end{array}$ & $\begin{array}{l}5.19 \\
7.43\end{array}$ & $\begin{array}{l}5.18 \\
7.41\end{array}$ \\
\hline $\mathrm{Fe}+2 / \mathrm{Fe}+3$ & 0.23 & 0.22 & 0.21 & 0.20 & 0.21 & 0.21 \\
\hline
\end{tabular}




\section{LABORATORY ANALYSIS REPORT}

CELS Client No.: 11988-036

Exhibit A: Quantitative Chemical Analysis

Sample Description: 1000 lb. Standard

Sample 4

Dissolution 1 Dissolution 2 Dissolution 3 Read 1 Read 2 Read 1 Read 2 Read 1 Read 2

\begin{tabular}{|c|c|c|c|c|c|c|}
\hline $\begin{array}{l}\text { Al203 } \\
\text { B2O3 } \\
\text { CaO } \\
\text { Fe2O3 } \\
\text { FeO } \\
\text { K2O } \\
\text { La2O3 } \\
\text { Li2O } \\
\text { MgO } \\
\text { MnO } \\
\text { Na2O } \\
\text { NiO } \\
\text { SiO2 } \\
\text { TiO2 } \\
\text { ZrO2 }\end{array}$ & $\begin{array}{l}3.67 \\
11.1 \\
1.11 \\
7.33 \\
1.42 \\
0.04 \\
0.41 \\
4.28 \\
1.70 \\
1.33 \\
16.8 \\
0.56 \\
48.2 \\
0.69 \\
0.45\end{array}$ & $\begin{array}{l}3.67 \\
11.1 \\
1.11 \\
7.34 \\
1.43 \\
0.04 \\
0.41 \\
4.28 \\
1.70 \\
1.33 \\
16.9 \\
0.56 \\
48.5 \\
0.69 \\
0.45\end{array}$ & $\begin{array}{l}3.75 \\
11.3 \\
1.13 \\
7.49 \\
1.42 \\
0.04 \\
0.42 \\
4.26 \\
1.73 \\
1.35 \\
16.8 \\
0.57 \\
49.1 \\
0.70 \\
0.47\end{array}$ & $\begin{array}{l}3.72 \\
11.2 \\
1.12 \\
7.45 \\
1.41 \\
0.04 \\
0.42 \\
4.26 \\
1.72 \\
1.35 \\
16.99 \\
0.57 \\
48.8 \\
0.70 \\
0.47\end{array}$ & $\begin{array}{l}3.68 \\
11.4 \\
1.11 \\
7.39 \\
1.40 \\
0.04 \\
0.41 \\
4.26 \\
1.71 \\
1.35 \\
16.8 \\
0.57 \\
48.6 \\
0.69 \\
0.45\end{array}$ & $\begin{array}{l}3.69 \\
11.4 \\
1.12 \\
7.41 \\
1.40 \\
0.04 \\
0.41 \\
4.26 \\
1.72 \\
1.35 \\
16.7 \\
0.57 \\
48.8 \\
0.69 \\
0.45\end{array}$ \\
\hline Total & 99.09 & 99.51 & 100.53 & 100.13 & 99.86 & 100.01 \\
\hline $\begin{array}{l}\text { Fe 203(TOT) } \\
\text { Fe (TOT) }\end{array}$ & $\begin{array}{l}8.91 \\
6.23\end{array}$ & $\begin{array}{l}8.93 \\
6.24\end{array}$ & $\begin{array}{l}9.07 \\
6.34\end{array}$ & $\begin{array}{l}9.02 \\
6.30\end{array}$ & $\begin{array}{l}8.95 \\
6.26\end{array}$ & $\begin{array}{l}8.97 \\
6.27\end{array}$ \\
\hline $\begin{array}{l}\text { Feo } \\
\operatorname{Fe}(+2)\end{array}$ & $\begin{array}{l}1.42 \\
1.10\end{array}$ & $\begin{array}{l}1.43 \\
1.11\end{array}$ & $\begin{array}{l}1.42 \\
1.10\end{array}$ & $\begin{array}{l}1.41 \\
1.10\end{array}$ & $\begin{array}{l}1.40 \\
1.09\end{array}$ & $\begin{array}{l}1.40 \\
1.09\end{array}$ \\
\hline $\begin{array}{l}\operatorname{Fe}(+3) \\
\operatorname{Fe} 203(+3)\end{array}$ & $\begin{array}{l}5.12 \\
7.33\end{array}$ & $\begin{array}{l}5.13 \\
7.34\end{array}$ & $\begin{array}{l}5.24 \\
7.49\end{array}$ & $\begin{array}{l}5.21 \\
7.45\end{array}$ & $\begin{array}{l}5.17 \\
7.39\end{array}$ & $\begin{array}{l}5.18 \\
7.41\end{array}$ \\
\hline $\mathrm{Fe}+2 / \mathrm{Fe}+3$ & 0.22 & 0.22 & 0.21 & 0.21 & 0.21 & 0.21 \\
\hline
\end{tabular}




\section{LABORATORY ANALYSIS REPORT}

CELS Client No.: 11988-036

Exhibit A: Quantitative Chemical Analysis

Sample Description: 1000 lb. Standard

Sample 5

Dissolution 1 Dissolution 2 Dissolution 3 Read 1 Read $2 \operatorname{Read} 1$ Read 2 Read 1 Read 2

\begin{tabular}{|c|c|c|c|c|c|c|}
\hline $\begin{array}{l}\mathrm{A} 1203 \\
\mathrm{~B} 203 \\
\mathrm{CaO} \\
\mathrm{Fe} 203 \\
\mathrm{FeO} \\
\mathrm{K} 2 \mathrm{O} \\
\mathrm{La2O3} \\
\mathrm{Li} 20 \\
\mathrm{MgO} \\
\mathrm{MnO} \\
\mathrm{Na2O} \\
\mathrm{NiO} \\
\mathrm{SiO} 2 \\
\mathrm{TiO} \\
\mathrm{ZrO}\end{array}$ & $\begin{array}{l}3.70 \\
11.3 \\
1.11 \\
7.31 \\
1.48 \\
0.04 \\
0.42 \\
4.28 \\
1.71 \\
1.33 \\
16.8 \\
0.56 \\
48.5 \\
0.69 \\
0.47\end{array}$ & $\begin{array}{l}3.68 \\
11.3 \\
1.11 \\
7.29 \\
1.49 \\
0.04 \\
0.41 \\
4.29 \\
1.70 \\
1.33 \\
16.9 \\
0.57 \\
48.4 \\
0.69 \\
0.47\end{array}$ & $\begin{array}{l}3.70 \\
11.2 \\
1.12 \\
7.35 \\
1.48 \\
0.04 \\
0.41 \\
4.28 \\
1.71 \\
1.34 \\
16.9 \\
0.57 \\
48.6 \\
0.70 \\
0.48\end{array}$ & $\begin{array}{l}3.72 \\
11.2 \\
1.13 \\
7.41 \\
1.49 \\
0.04 \\
0.42 \\
4.25 \\
1.73 \\
1.35 \\
16.9 \\
0.58 \\
49.0 \\
0.70 \\
0.48\end{array}$ & $\begin{array}{l}3.69 \\
11.4 \\
1.12 \\
7.38 \\
1.46 \\
0.04 \\
0.41 \\
4.23 \\
1.73 \\
1.35 \\
16.7 \\
0.57 \\
48.9 \\
0.69 \\
0.46\end{array}$ & $\begin{array}{l}3.69 \\
11.4 \\
1.12 \\
7.35 \\
1.45 \\
0.04 \\
0.41 \\
4.26 \\
1.72 \\
1.35 \\
16.7 \\
0.57 \\
48.7 \\
0.69 \\
0.46\end{array}$ \\
\hline Total & 99.70 & 99.67 & 99.88 & 100.40 & 100.13 & 99.91 \\
\hline $\begin{array}{l}\text { Fe 203(TOT) } \\
\text { Fe (TOT) }\end{array}$ & $\begin{array}{l}8.96 \\
6.26\end{array}$ & $\begin{array}{l}8.95 \\
6.26\end{array}$ & $\begin{array}{l}9.00 \\
6.29\end{array}$ & $\begin{array}{l}9.07 \\
6.34\end{array}$ & $\begin{array}{l}9.01 \\
6.30\end{array}$ & $\begin{array}{l}8.97 \\
6.27\end{array}$ \\
\hline $\begin{array}{l}\text { FeO } \\
\mathrm{Fe}(+2)\end{array}$ & $\begin{array}{l}1.48 \\
1.15\end{array}$ & $\begin{array}{l}1.49 \\
1.16\end{array}$ & $\begin{array}{l}1.48 \\
1.15\end{array}$ & $\begin{array}{l}1.49 \\
1.16\end{array}$ & $\begin{array}{l}1.46 \\
1.13\end{array}$ & $\begin{array}{l}1.45 \\
1.13\end{array}$ \\
\hline $\begin{array}{l}\mathrm{Fe}(+3) \\
\mathrm{Fe} 203(+3)\end{array}$ & $\begin{array}{l}5.11 \\
7.31\end{array}$ & $\begin{array}{l}5.10 \\
7.29\end{array}$ & $\begin{array}{l}5.14 \\
7.35\end{array}$ & $\begin{array}{l}5.18 \\
7.41\end{array}$ & $\begin{array}{l}5.16 \\
7.38\end{array}$ & $\begin{array}{l}5.14 \\
7.35\end{array}$ \\
\hline $\mathrm{Fe}+2 / \mathrm{Fe}+3$ & 0.22 & 0.23 & 0.22 & 0.22 & 0.22 & 0.22 \\
\hline
\end{tabular}




\section{LABORATORY ANALYSIS REPORT}

CELS Client No.: 11988-036

Exhibit A: Quantitative Chemical Analysis

Sample Description: 1000 lb. Standard

summary

\begin{tabular}{|c|c|c|c|c|c|c|}
\hline & Target & $+1-$ & Mean & Dif & std Dev & RSD (z) \\
\hline $\begin{array}{l}\mathrm{Al} 203 \\
\mathrm{~B} 203 \\
\mathrm{CaO} \\
\mathrm{Fe} 203 \\
\mathrm{FeO} \\
\mathrm{K} 2 \mathrm{O} \\
\mathrm{La2O3} \\
\mathrm{Li2O} \\
\mathrm{MgO} \\
\mathrm{MnO} \\
\mathrm{Na2O} \\
\mathrm{NiO} \\
\mathrm{SiO} 2 \\
\mathrm{TiO} 2 \\
\mathrm{ZrO} 2\end{array}$ & $\begin{array}{r}3.67 \\
11.1 \\
1.13 \\
8.08 \\
0.89 \\
0.04 \\
0.41 \\
4.28 \\
1.66 \\
1.34 \\
16.7 \\
0.61 \\
48.95 \\
0.71 \\
0.41\end{array}$ & $\begin{array}{l}0.18 \\
0.56 \\
0.06 \\
0.40 \\
0.004 \\
0.04 \\
0.21 \\
0.08 \\
0.07 \\
0.84 \\
0.06 \\
4.49 \\
0.07 \\
0.04\end{array}$ & $\begin{array}{r}3.70 \\
11.3 \\
1.12 \\
7.38 \\
1.45 \\
0.04 \\
0.42 \\
4.26 \\
1.72 \\
1.34 \\
16.8 \\
0.57 \\
48.73 \\
0.70 \\
0.46\end{array}$ & $\begin{array}{r}0.03 \\
0.2 \\
-0.01 \\
-0.70 \\
0.00 \\
0.01 \\
-0.02 \\
0.06 \\
0.00 \\
0.10 \\
-0.04 \\
-0.22 \\
-0.01 \\
0.05\end{array}$ & $\begin{array}{l}0.023 \\
0.097 \\
0.007 \\
0.074 \\
0.041 \\
0.000 \\
0.005 \\
0.015 \\
0.011 \\
0.010 \\
0.061 \\
0.005 \\
0.302 \\
0.006 \\
0.012\end{array}$ & $\begin{array}{l}0.6 \\
0.9 \\
0.6 \\
1.0 \\
2.9 \\
0.0 \\
1.2 \\
0.4 \\
0.6 \\
0.8 \\
0.4 \\
0.9 \\
0.6 \\
0.8 \\
2.7\end{array}$ \\
\hline Total & 99.99 & & 99.96 & & & \\
\hline Redox & $.1-.3$ & & .22 & & & \\
\hline $\begin{array}{l}\ddot{2} F_{e} \text { an } \\
F_{2 i 3}\end{array}$ & 9.077 & & 8.99 & & & \\
\hline
\end{tabular}




\section{APPENDIX II Savannah River Technology Center Chemical Analysis of EA Glass}

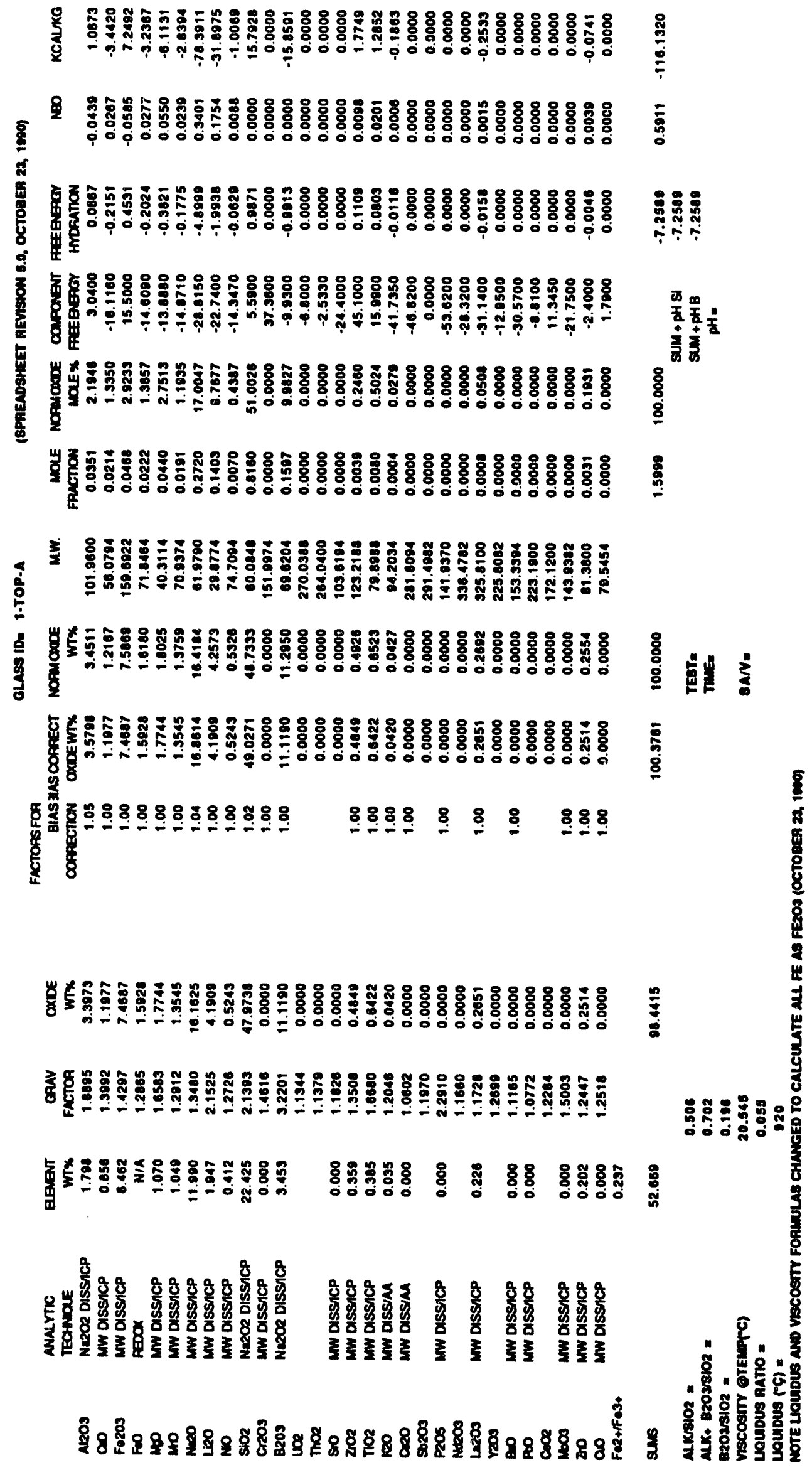




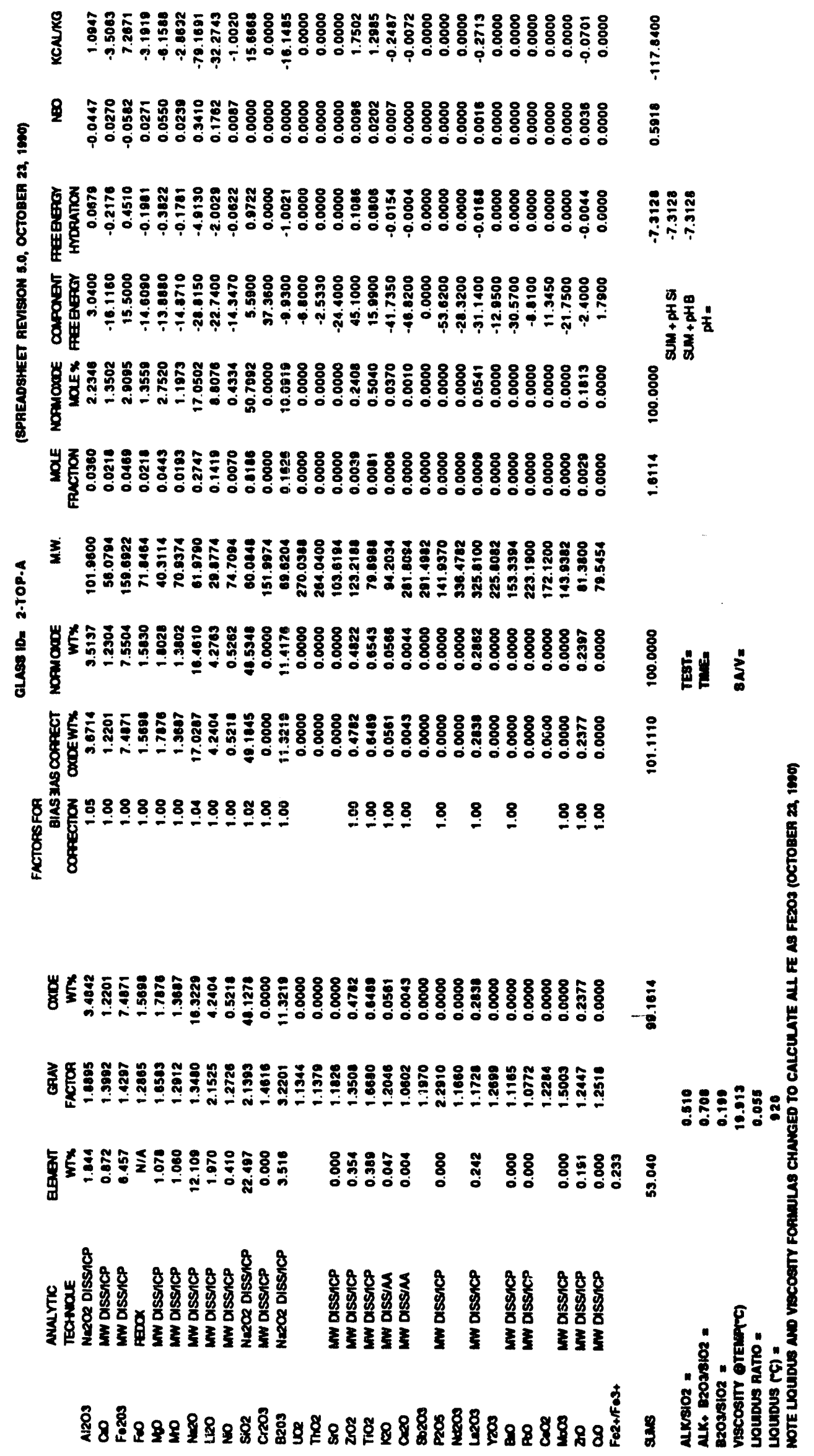




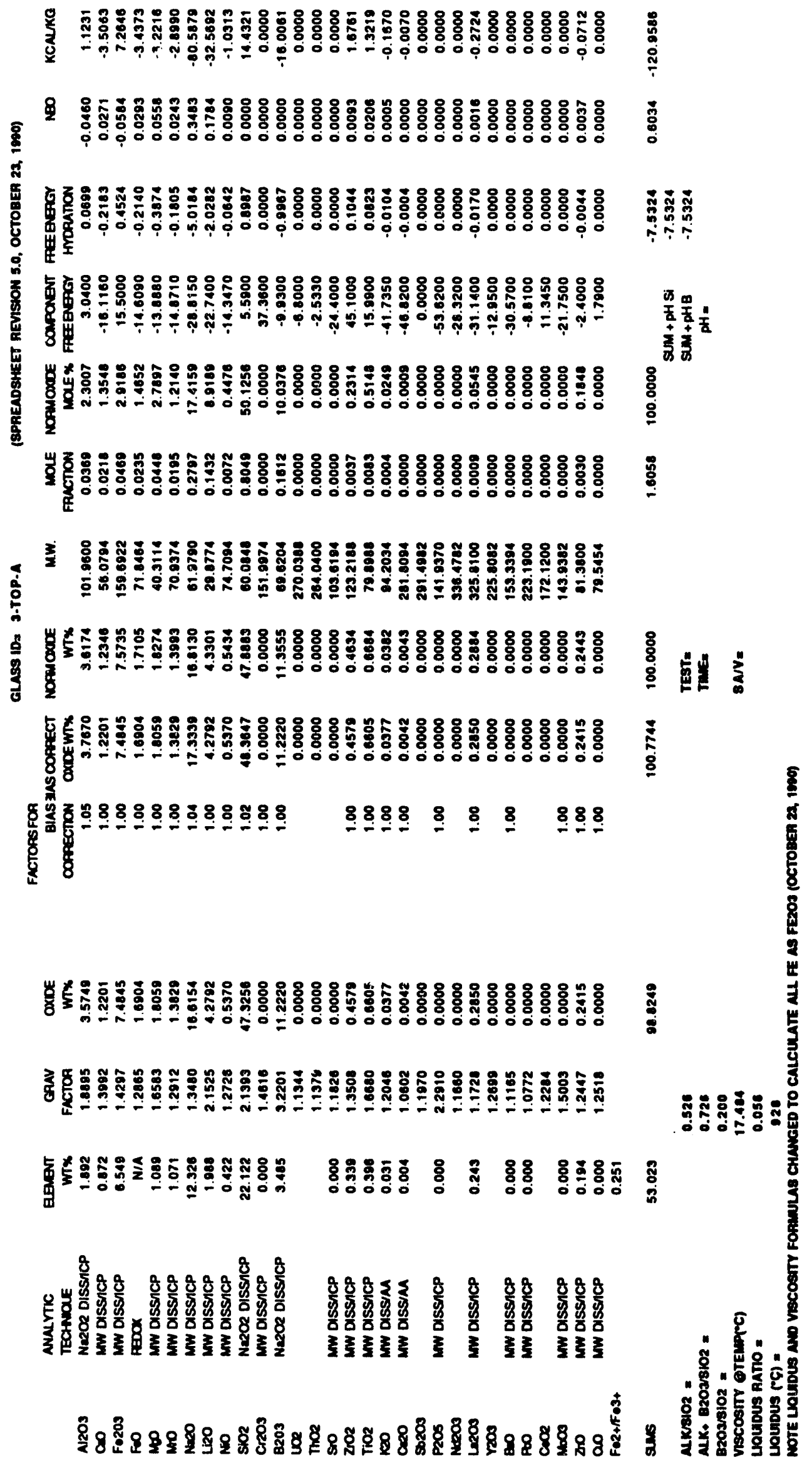




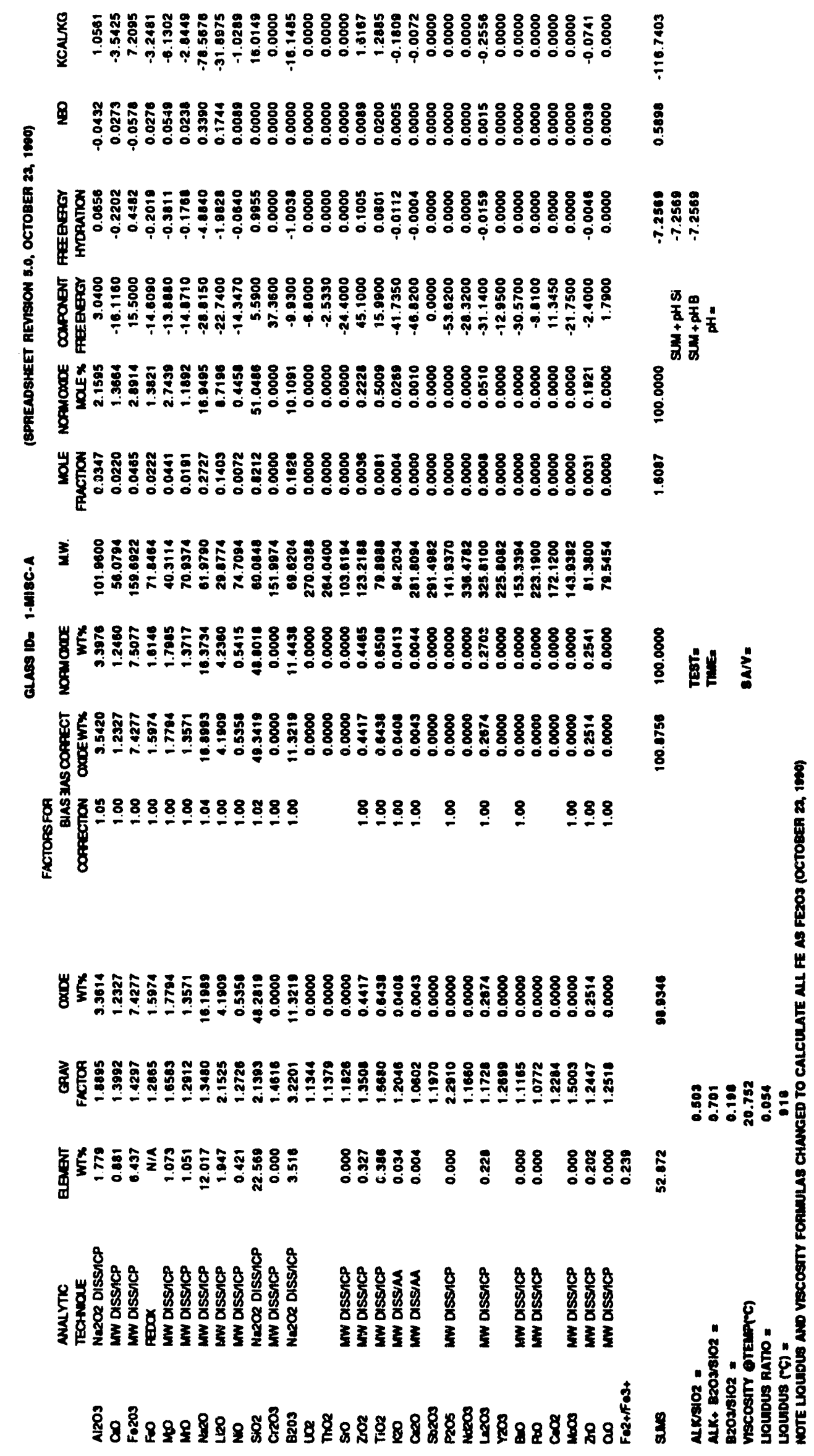




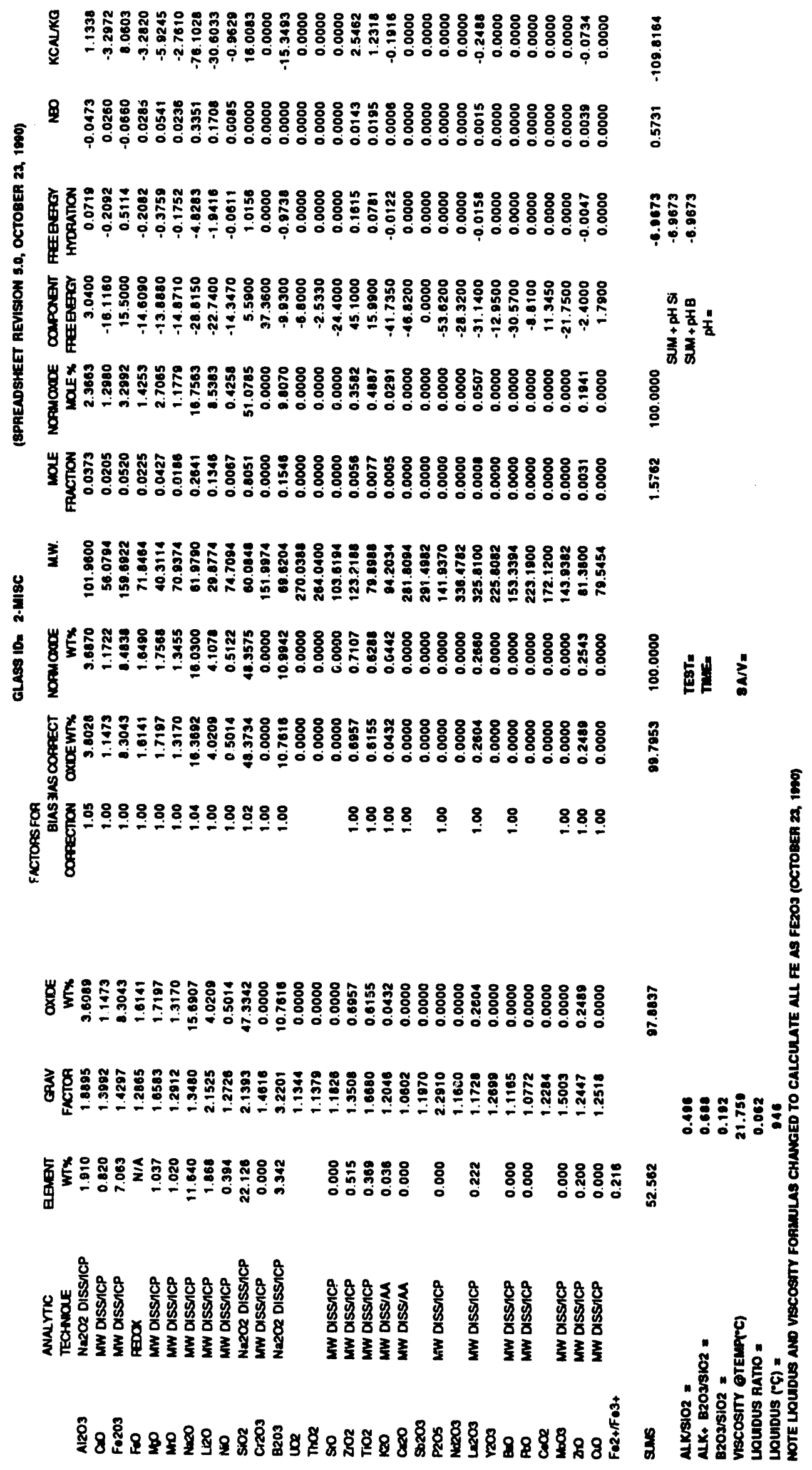




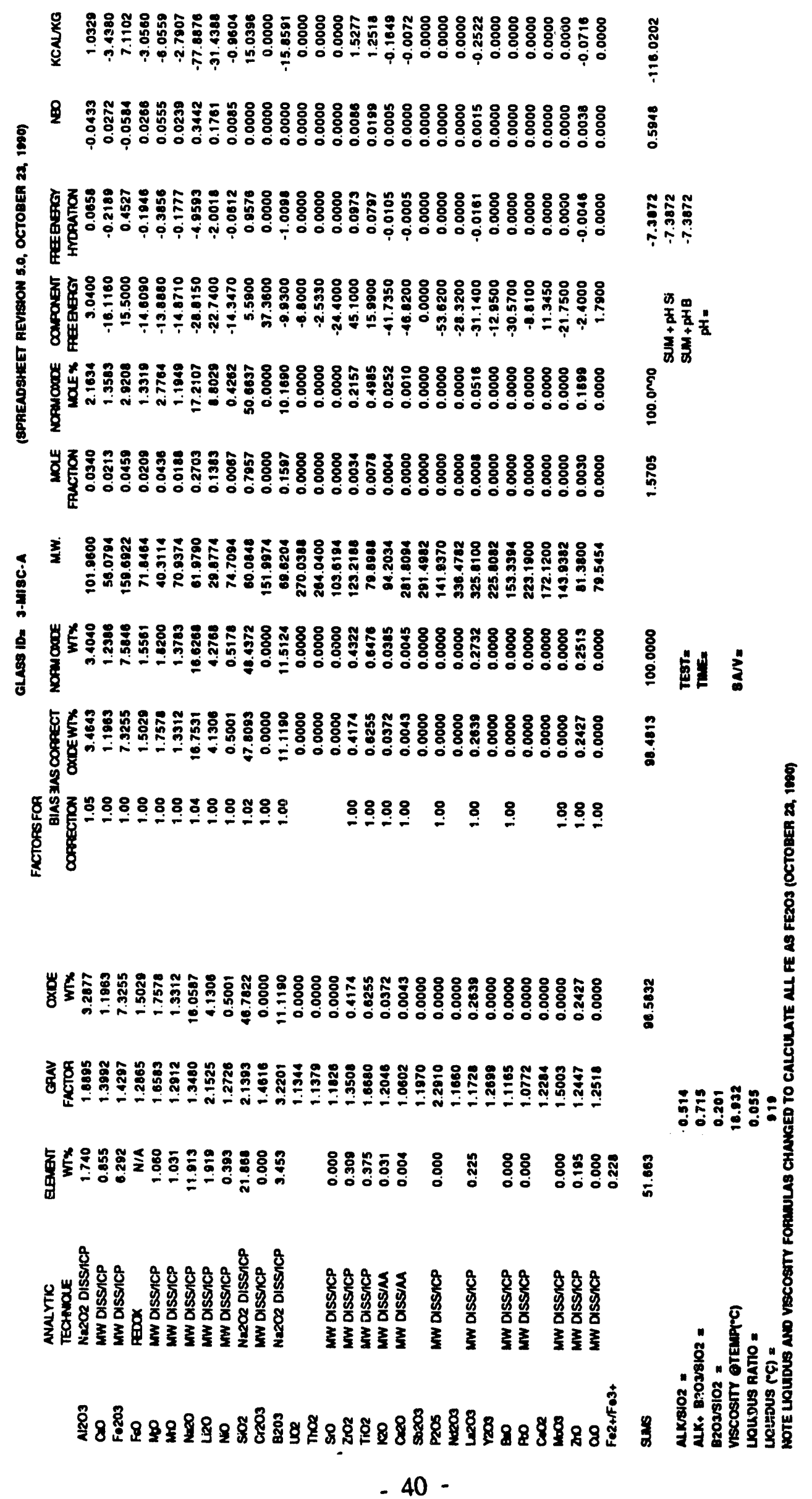




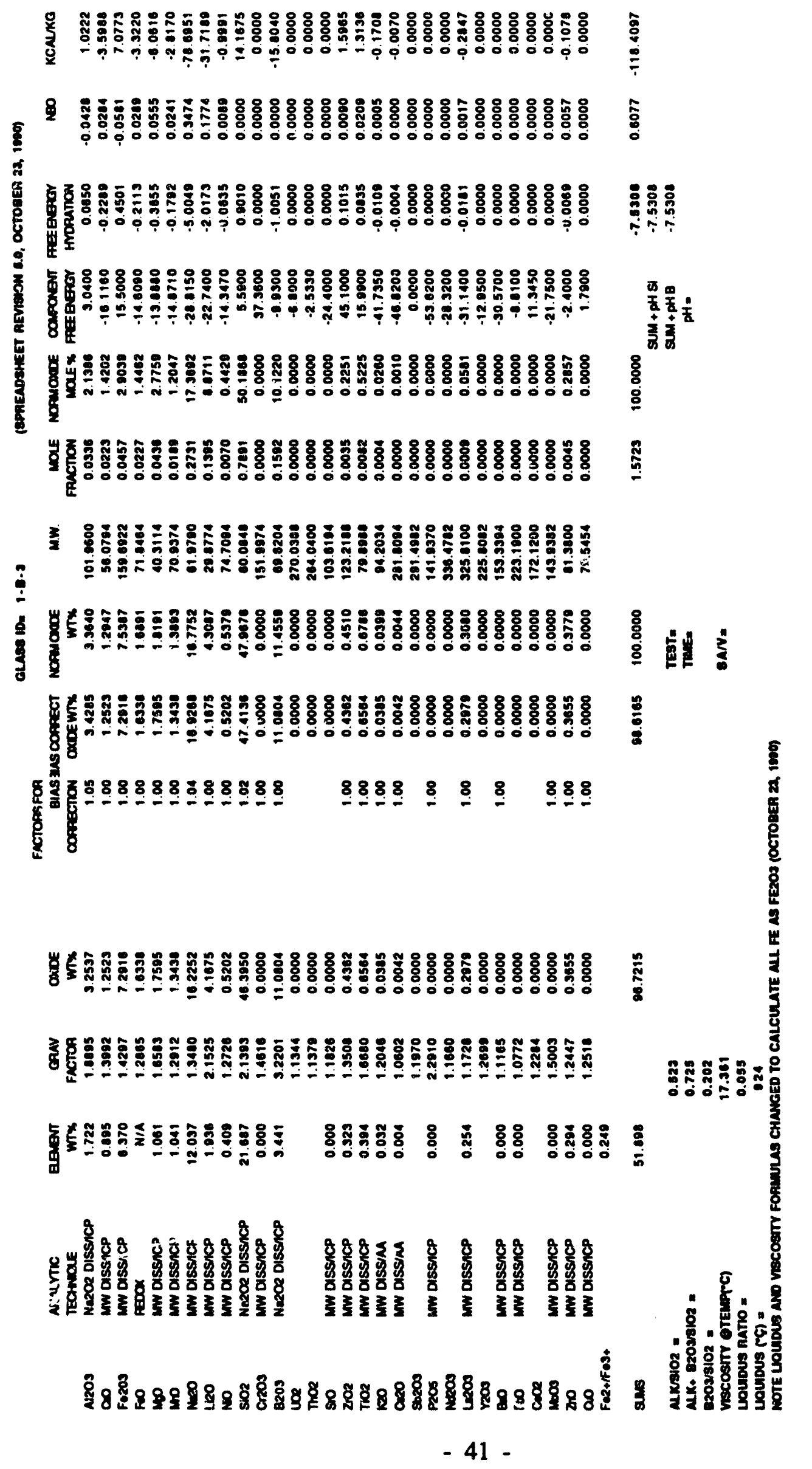




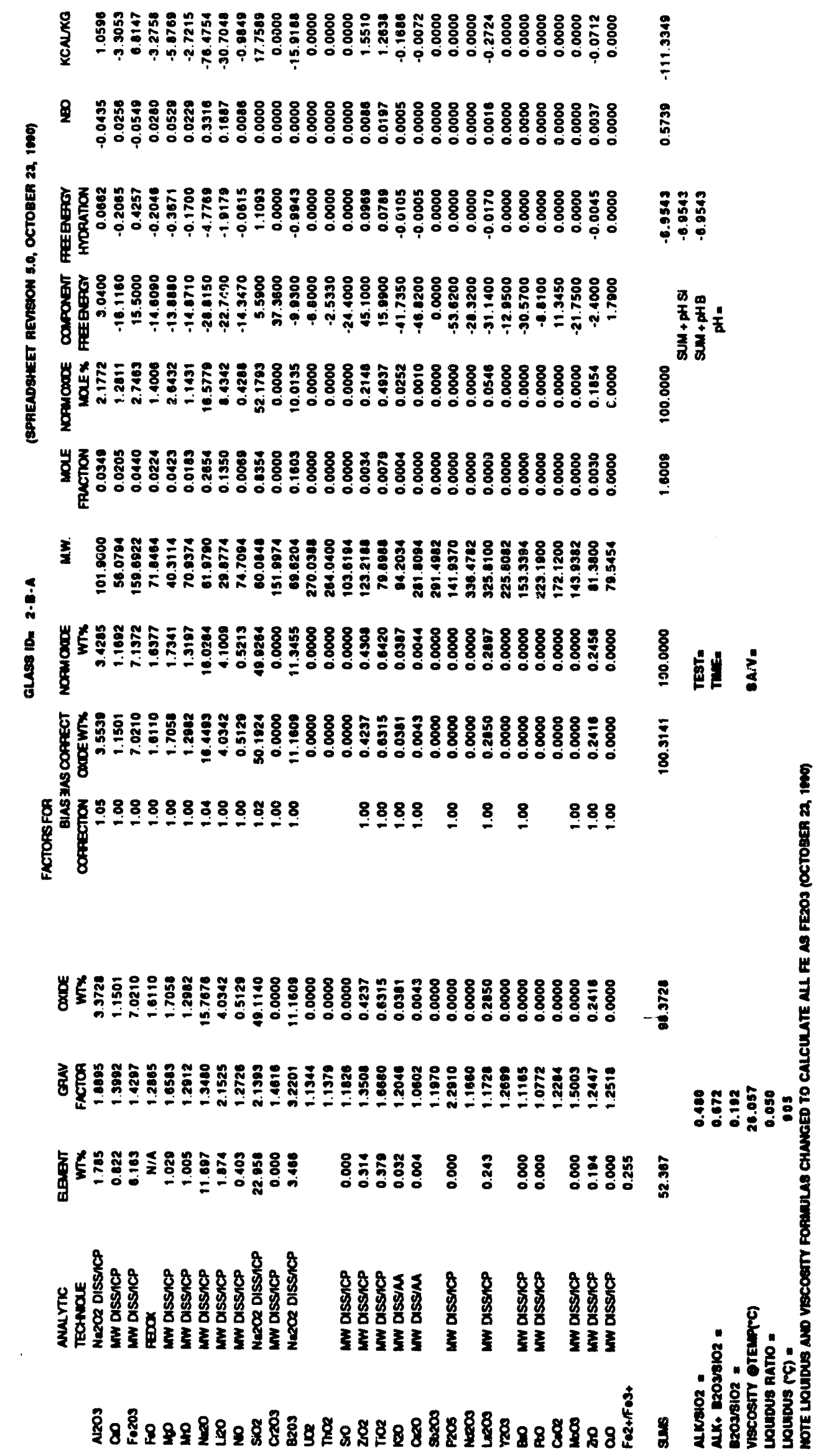




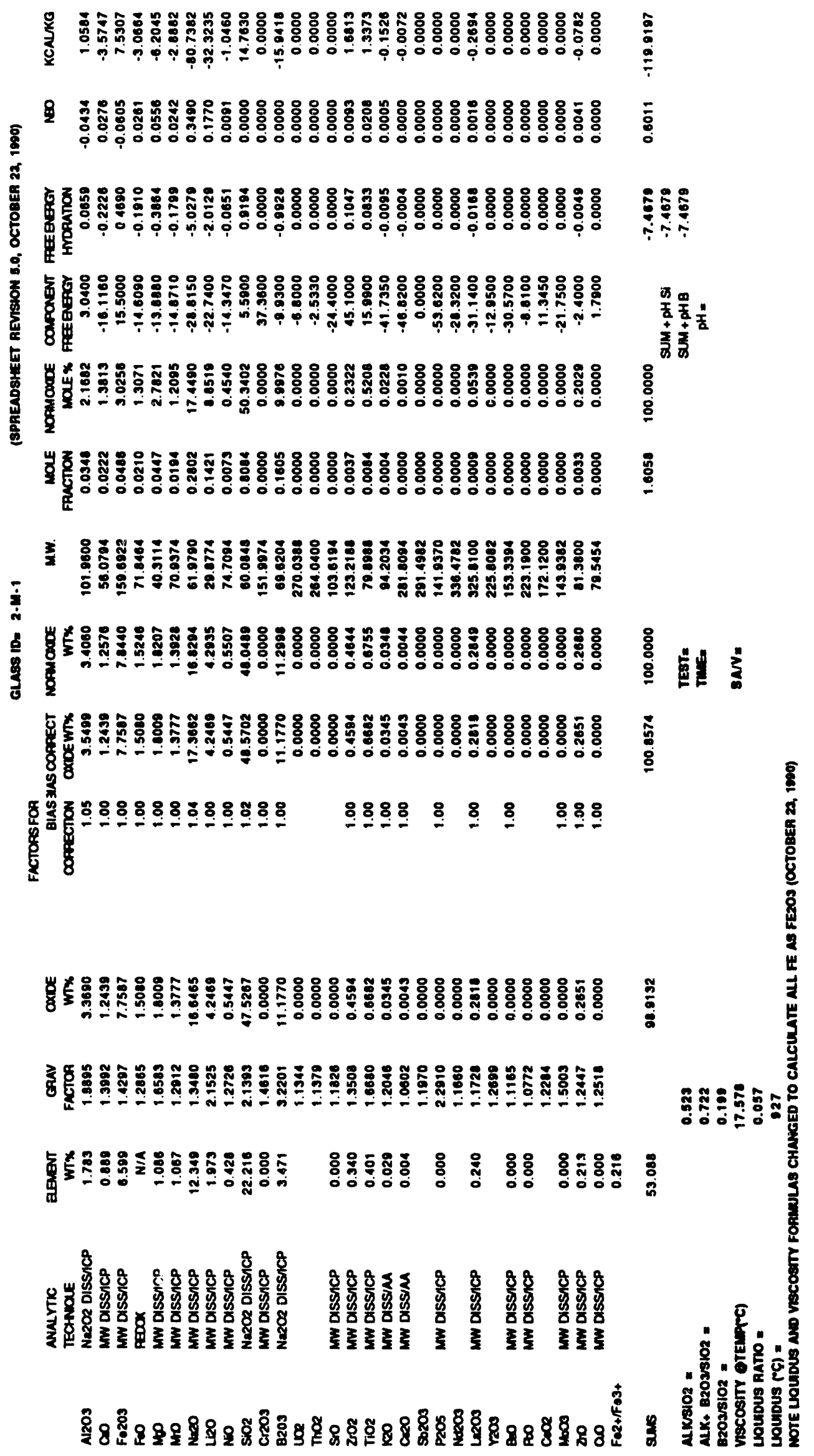




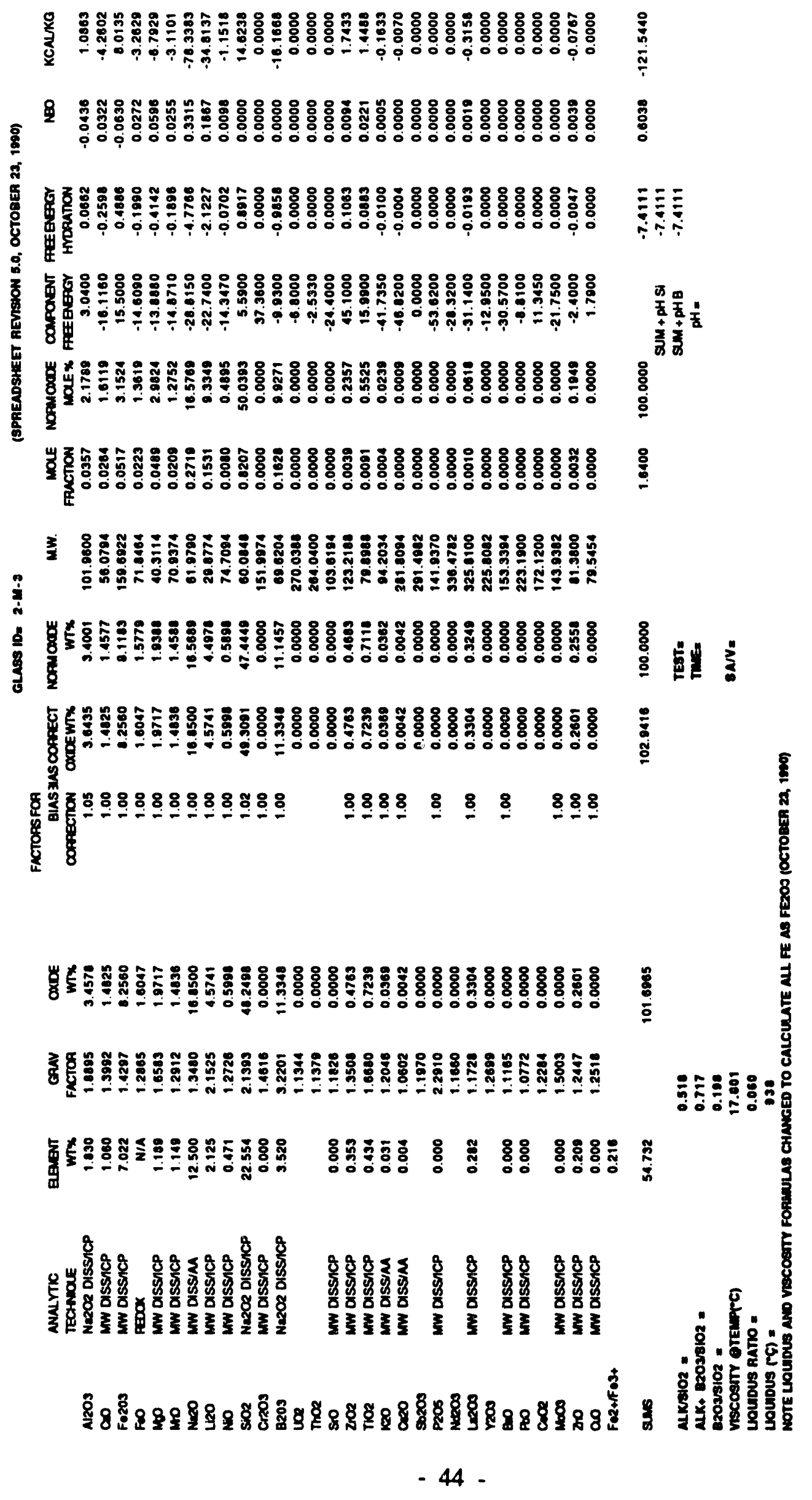




\section{APPENDIX III Multielement Solution Standard Analysis - Researcher I}

\begin{tabular}{|c|c|c|c|c|c|c|c|c|c|}
\hline Eloment & $\begin{array}{l}\text { Concentration } \\
\text { of Multiebement } \\
\text { Standaro ug/mL) }\end{array}$ & $\begin{array}{r}\text { Run belore } \\
\text { Samples-1 } \\
\text { ug/mL }\end{array}$ & $\begin{array}{r}\text { Run bolore } \\
\text { Sumples-2 } \\
\text { ug/mL }\end{array}$ & $\begin{array}{r}\text { Run atter } 5 \\
\text { Samples-1 } \\
u g / m L\end{array}$ & $\begin{array}{c}\text { Pun atier } 5 \\
\text { Samples-2 } \\
\text { ug/mL }\end{array}$ & $\begin{array}{r}\text { Run aftor } 10 \\
\text { Samples }-1 \\
u g / m L\end{array}$ & $\begin{array}{r}\text { Run athor } 10 \\
\text { Samplos-2 } \\
\text { ug/mL }\end{array}$ & $\begin{array}{r}\text { Aun atrof } 15 \\
\text { Samples-1 } \\
\text { ug/mL }\end{array}$ & $\begin{array}{r}\text { Run after } 15 \\
\text { Samples-2 } \\
\text { ug/mL. }\end{array}$ \\
\hline $\mathrm{Na}$ (ICP) & 50.10 & 49.20 & 49.62 & 49.00 & 49.55 & 49.55 & 49.52 & 49.30 & 49.34 \\
\hline $\operatorname{Na}(\boldsymbol{A})$ & & 46.12 & 45.00 & 47.18 & 46.35 & 49.31 & 52.13 & 51.09 & 62.13 \\
\hline $\mathbf{S i}$ & 50.10 & 44.68 & 44.08 & 45.41 & 45.17 & 45.34 & 45.05 & 45.15 & 44.91 \\
\hline $\mathbf{B}$ & 20.00 & 19.64 & 15.74 & 10.81 & 10.75 & 19.76 & 19.73 & 19.81 & 19.80 \\
\hline $\mathbf{K}$ & 10.00 & 9.05 & 0.62 & 9.56 & 8.50 & 9.52 & 0.65 & 0.79 & 0.61 \\
\hline LI & 10.00 & 2.88 & 9.93 & 9.96 & 9.94 & 0.04 & 0.92 & 9.80 & 9.88 \\
\hline Al & 4.08 & $3 . i$ & 3.42 & 3.37 & 3.36 & 3.33 & 3.27 & 3.32 & 3.20 \\
\hline Fe & 3.98 & 4.19 & 4.21 & 4.21 & 4.21 & 4.21 & 4.20 & 4.10 & 4.10 \\
\hline Eloment & Concentration & Average Blas & & Average Bias & & Averace Blas & & Avereqp Bies & \\
\hline & $\begin{array}{c}\text { of Mulielement bel } \\
\text { Standard } \\
\text { ug/mL }\end{array}$ & $\begin{array}{r}\text { More Leachate } \\
\text { Analyeis } \\
\text { ug/mL }\end{array}$ & & $\begin{array}{r}5 \text { Leachate } \\
\text { Analyeos } \\
\mathrm{ug} / \mathrm{mL}\end{array}$ & after & $\begin{array}{r}10 \text { Leachate } \\
\text { Analysees } \\
\text { ug/mL }\end{array}$ & atter & $\begin{array}{r}15 \text { Leachate } \\
\text { Analyees } \\
\text { ug/mL }\end{array}$ & \\
\hline$N \cdot(K C P)$ & 50.10 & .0 .60 & & -0.82 & & $\cdot 0.57$ & & -0.74 & \\
\hline$N a(M)$ & & -4.39 & & $\cdot 3.34$ & & 0.62 & & 1.51 & \\
\hline SI & 50.10 & .5 .28 & & -4.81 & & -4.01 & & -5.07 & \\
\hline $\mathbf{B}$ & 20.00 & -0.31 & & -0.22 & & -0.25 & & .0 .30 & \\
\hline$K$ & 10.00 & $\cdot 0.42$ & & -0.47 & & -0.42 & & -0.30 & \\
\hline LI & 10.00 & .0 .10 & & .0 .05 & & -0.07 & & -0.12 & \\
\hline $\begin{array}{l}A_{1} \\
F_{0}\end{array}$ & $\begin{array}{l}4.06 \\
3.98\end{array}$ & $\begin{array}{r}-0.62 \\
0.22\end{array}$ & & $\begin{array}{r}-0.70 \\
0.23\end{array}$ & & $\begin{array}{r}-0.76 \\
0.22\end{array}$ & & $\begin{array}{r}-0.78 \\
0.21\end{array}$ & \\
\hline
\end{tabular}

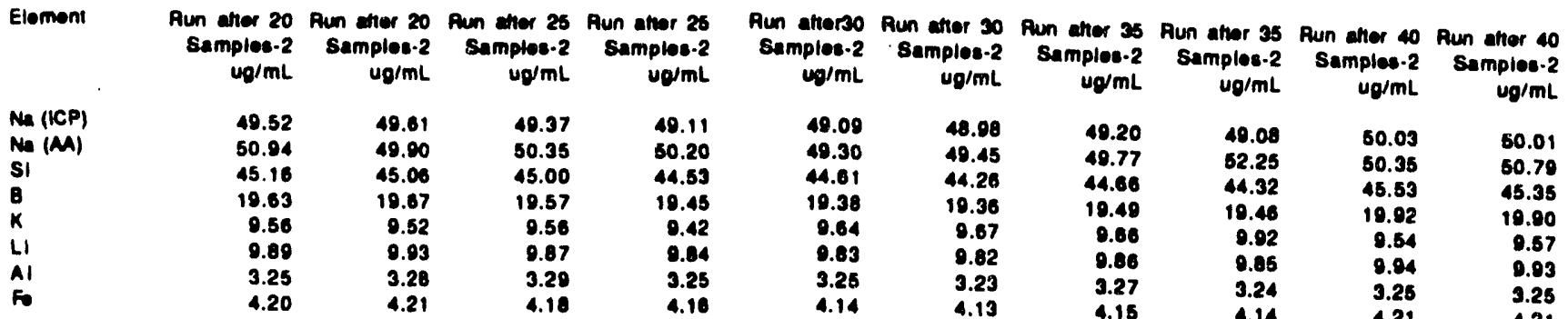

\begin{tabular}{|c|c|c|c|c|c|}
\hline Elomem & $\begin{array}{r}\text { Awrege Bias } \\
\text { atrer } 20 \text { Leachate } \\
\text { Analysees } \\
u g / m L\end{array}$ & $\begin{array}{r}\text { Averege Blas } \\
\text { anor } 25 \text { Leachate } \\
\text { Analyees } \\
\text { ug/mL }\end{array}$ & $\begin{array}{r}\text { Awrege Bias } \\
\text { ather so Leachate } \\
\text { Analyeses } \\
40 / \mathrm{mL}\end{array}$ & $\begin{array}{r}\text { Averege Blas } \\
\text { aher } 35 \text { Loachate } \\
\text { Analyses } \\
\text { Ua/mL. }\end{array}$ & $\begin{array}{r}\text { Average Bias } \\
\text { entor } 40 \text { Leachaie } \\
\text { Analyees } \\
\text { ug/mL }\end{array}$ \\
\hline $\operatorname{Na}$ (ICP) & -0.53 & -0.86 & -1.07 & .0 .08 & .0 .08 \\
\hline $\begin{array}{l}\text { Na }(M) \\
\text { SI }\end{array}$ & $\begin{array}{r}0.32 \\
-4.99\end{array}$ & $\begin{array}{r}0.18 \\
.5 .34\end{array}$ & $\begin{array}{l}-0.73 \\
-5.67\end{array}$ & $\begin{array}{r}0.01 \\
-5.61\end{array}$ & $\begin{array}{r}0.47 \\
.4 .68\end{array}$ \\
\hline B & -0.35 & -0.49 & -0.63 & -0.52 & .0 .00 \\
\hline $\begin{array}{l}K \\
L I\end{array}$ & -0.46 & .0 .51 & $\cdot 0.35$ & -0.21 & -0.45 \\
\hline $\begin{array}{l}\text { LI } \\
\text { Al }\end{array}$ & -0.09 & .0 .15 & -0.18 & -0.14 & -0.07 \\
\hline $\begin{array}{l}A_{1} \\
F_{0}\end{array}$ & $\begin{array}{r}-0.60 \\
0.22\end{array}$ & $\begin{array}{r}-0.70 \\
0.19\end{array}$ & $\begin{array}{r}-0.82 \\
0.15\end{array}$ & $\begin{array}{r}-0.81 \\
0.16\end{array}$ & $\begin{array}{r}-0.81 \\
0.23\end{array}$ \\
\hline
\end{tabular}



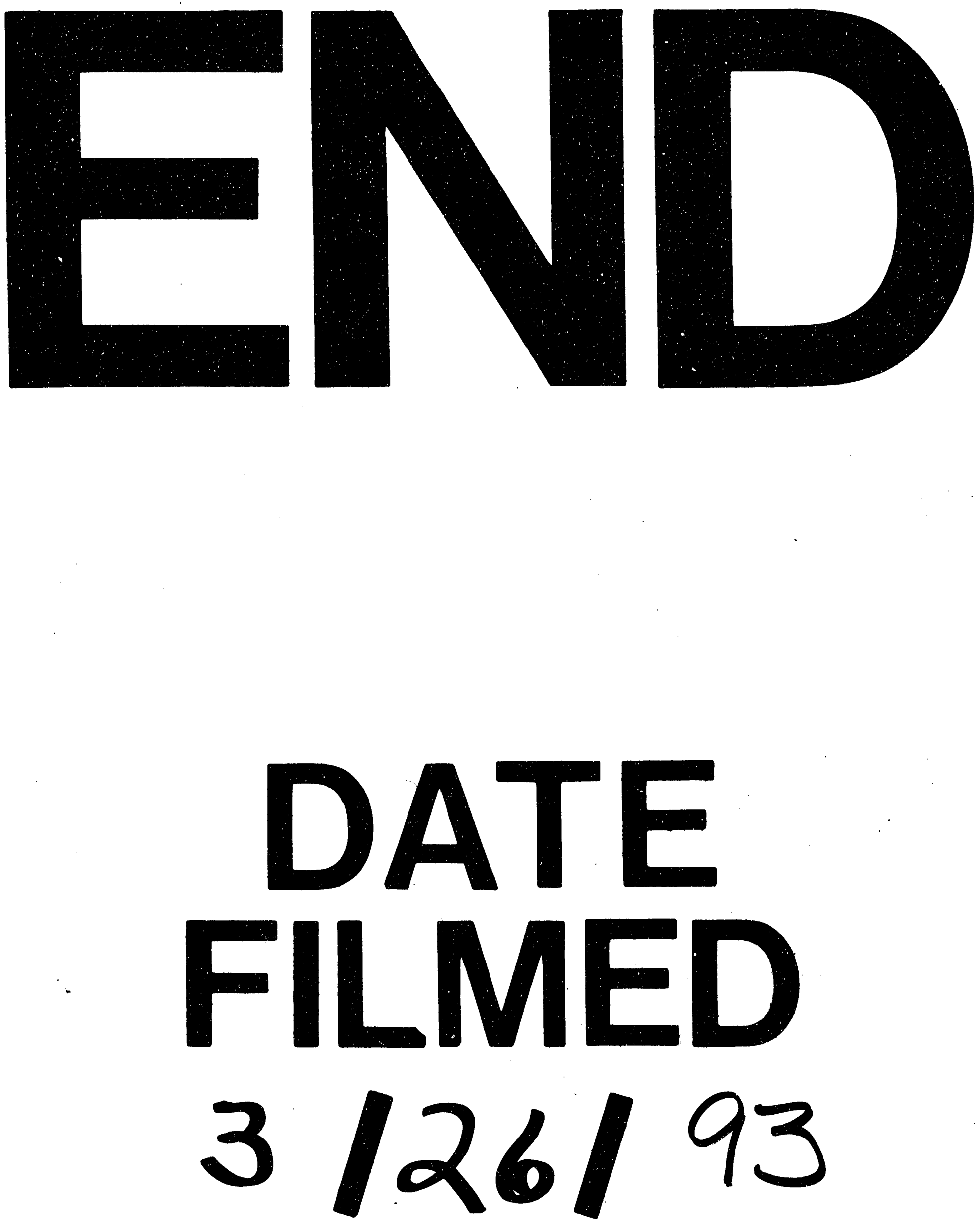
